\title{
Suburbia Redux:
}

\section{Recycling the American Dream}

by

Kristen Tuttle

A thesis submitted to The Faculty of Graduate and Postdoctoral Affairs

in partial fulfillment of the requirements for the degree of

Master of Architecture

In

M. Arch. Professional

Carleton University,

Azrieli School of Architecture and Urbanism

Ottawa, ON

(C)2011-2012

Kristen Tuttle 
Library and Archives

Canada

Published Heritage

Branch

395 Wellington Street

Ottawa ON K1A ON4

Canada
Bibliothèque et

Archives Canada

Direction du

Patrimoine de l'édition

395 , rue Wellington

Ottawa ON K1A ON4

Canada
Your file Votre référence

ISBN: 978-0-494-91529-5

Our file Notre référence

ISBN: $978-0-494-91529-5$
NOTICE:

The author has granted a nonexclusive license allowing Library and Archives Canada to reproduce, publish, archive, preserve, conserve, communicate to the public by telecommunication or on the Internet, loan, distrbute and sell theses worldwide, for commercial or noncommercial purposes, in microform, paper, electronic and/or any other formats.

The author retains copyright ownership and moral rights in this thesis. Neither the thesis nor substantial extracts from it may be printed or otherwise reproduced without the author's permission.
AVIS:

L'auteur a accordé une licence non exclusive permettant à la Bibliothèque et Archives Canada de reproduire, publier, archiver, sauvegarder, conserver, transmettre au public par télécommunication ou par l'Internet, prêter, distribuer et vendre des thèses partout dans le monde, à des fins commerciales ou autres, sur support microforme, papier, électronique et/ou autres formats.

L'auteur conserve la propriété du droit d'auteur et des droits moraux qui protege cette thèse. $\mathrm{Ni}$ la thèse ni des extraits substantiels de celle-ci ne doivent être imprimés ou autrement reproduits sans son autorisation.
In compliance with the Canadian Privacy Act some supporting forms may have been removed from this thesis.

While these forms may be included in the document page count, their removal does not represent any loss of content from the thesis.
Conformément à la loi canadienne sur la protection de la vie privée, quelques formulaires secondaires ont été enlevés de cette thèse.

Bien que ces formulaires aient inclus dans la pagination, il n'y aura aucun contenu manquant. 
Suburbia Redux: Recycling the American Dream

Kristen Tuttle,

M. Arch. Candidate

A thesis submitted to The Faculty of Graduate Studies and Postdoctoral Affairs in partial fulfillment of the requirements

for the degree of

MASTER OF ARCHITECTURE

in

M. Architecture Professional

Carleton University, Azrieli School of Architecture and Urbanism

Ottawa, Ontario

04.2012

(c) Copyright 2011-2012 Kristen R. Tuttle 


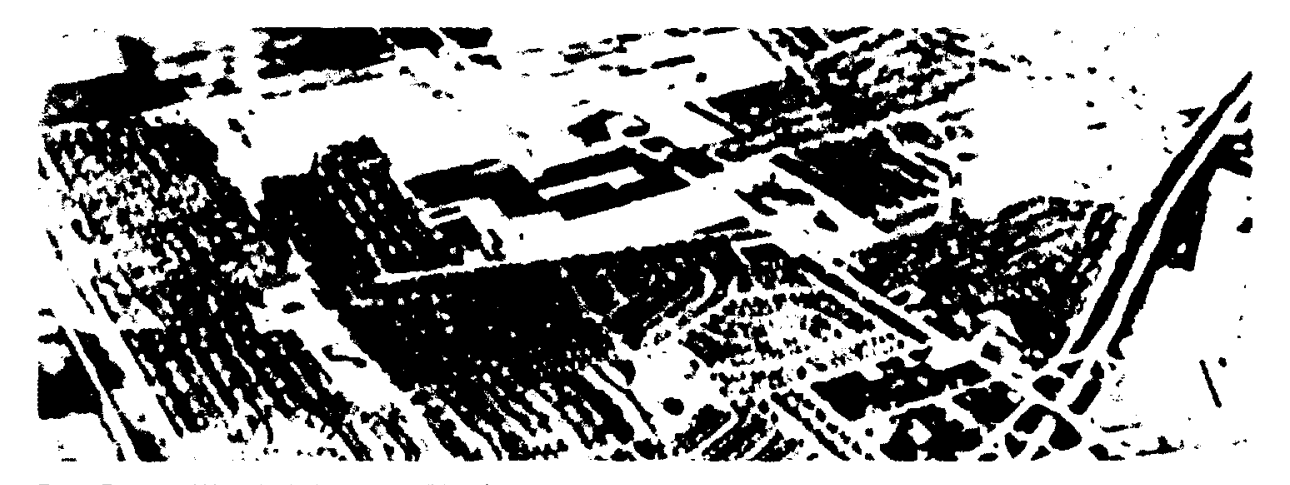

Fig 1. First post-War suburb: Levittown, NY, under construction. 1948. 


\section{ABSTRACT.}

America is currently facing a serious, yet unique housing problem. The Subprime Crisis and the collapse of the Unites States housing market have left millions of houses across America in various states of foreclosure. This crisis is especially pressing in suburbia, where the greatest casualties are oftentimes newly developed, oversized (and overly elaborate) homes, dubbed 'McMansions.' While this current epidemic of empty McMansions and foreclosed homes is an unfortunate reality, it presents an interesting opportunity to rethink and reframe our current definition of 'suburbia.'

This thesis aims to address the rise of foreclosed McMansions, while exploring ways of enriching and re-imagining the suburban landscape. Our current suburban reality is examined through the action of repurposing and reusing these 'mega' suburban homes. The McMansion will act as a reagent for the transformation of the suburban landscape into a more self-sufficient entity while encouraging community cohesion and social interaction amongst residents. Though the project will be conducted at a local scale and target a particular community, through one specific case study, the ideas and methodologies developed are imagined applicable across the United States. 
To my family, and friends.

for many great conversations and wonderful company during

my years in school.

A particular thank you to my colleagues with whom I shared a studio (514,) and to André, for the many very appreciated opinions and words of encouragement.

Sincerest thanks to my thesis advisor. Inderbir Singh Riar, for offering valuable insight, knowledge and guidance, and for sharing an enthusiasm about my thesis topic 
TABLE OF CONTENTS.

Abstract

Acknowledgements

iv

Table of Contents

Introduction

Section 1 Suburbanization + The Evolution of Housing [Post WWII-Present]

Chapter 1 - The American Dream.

Chapter 2 - (Sub) Urban Design History.

Chapter 3 - Genesis of Suburbia.

Chapter 4 - Evolution of the Suburban Home.

Chapter 5 - The McMansion + Living the McDream.

Section 2 The Financial Crisis + The American Nightmare

Chapter 6 - The Financial Crisis + The Crash of Wall Street.

Chapter 7 - Foreclosed | The American Nightmare.

\section{Section 3 | Project}

Chapter 8 - A Case Study. Repurposing the McMansion.

Site + Context of Case Study

Set of Parameters that Defined the Project

Defining the Program 


\section{INTRODUCTION.}

What is the American Dream? It is a difficult question to answer, not because the answer is unknown, but simply because it is like a dream - ethereal. However, at its core, the American Dream is a promise to American citizens: that through the freedom of the land, one's hard work can amount to prosperity and success, regardless of one's station or background. It is a powerful idea, and throughout American history it has shaped the way many Americans view

JOIN A HLLARIOUS ADYEMTUKE OF A LurE-TIM!

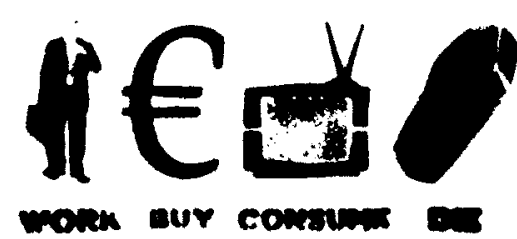

Fig. 2. Unknown Artist, Stencil art printed on various wails in Europe in 2007. not only themselves but their purpose in the world. Thus, it comes as no surprise to find how closely tied this idea of the American Dream is to the current culture of consumerism. One works harder to be increasingly successful and earn more money, and then validates his prosperity by buying 'things.' More things, better things, bigger things. In the end, no bought 'thing' personifies the American Dream perhaps more than the single family detached suburban house.

Homeownership was and remains a key part of the American Dream. It finds its roots as far back as the discovery of the country itself. The earliest European settlers who sailed across the Atlantic by choice perhaps did so because of the promise of cheap and vast farmland! They had an expectation of prosperity though work, much like many of today's American citizens, even given that the idea of 'prosperity' (and by extension what would constitute the American Dream) has shifted throughout the years. The idea can also be seen written into the Declaration of Independence, in which the founding fathers of America stated:

that all men are created equal, that they are endowed by their Creator with certain unalienable rights, that among these are life, liberty and the pursuit of happiness. ${ }^{2}$

' This idea is derived from the work completed by Frederick Turner in his thesis: The Significance of the Frontier in American History. In the thesis, he theorizes the origin of the distinct American character.

2 United States Declaration of Independence (1776) 
The colonial leaders perhaps wrote the document with the specific intention of denouncing monarchial laws and governance. However, the common man saw it as a statement from their leaders that put everyone on a metaphorical even footing: that any man, regardless of his position, had the ability to rise above his station to be greater than he was before ${ }^{3}$. It is specifically the idea of 'the pursuit of happiness' that would evolve into the more modern concept of the American Dream, and later become associated with material wealth.

The phrase 'The American Dream' however, didn't enter common parlance until much later, even though it's ideas had existed earlier as previously mentioned. The origin of the phrase can be traced to James Truslow Adams' 1931 book. The Epic of America. Adams aimed to find not how America became the nation it was, but why, and what made the country unlike any other that had come before it.

The American Dream has evolved beyond the idea of any single person being successful. Indeed, the idea of corporations, specifically, huge conglomerates, most of which were born in America, exemplify an amplified version of the American Dream. That is, these large corporations are largely concerned with profit. Many of the decisions made by the corporations involved with the 2007 financial crisis were heavily based on the improvement of their net earnings. Thus, these corporate entities also. then, ascribe to the American Dream (albeit different way from the average American). However, the actions of these corporations and the financial system played an extremely important part in understanding how people's 'American Dream' (i.e. homeownership) became twisted and fell apart into an American nightmare.

Prior to the 2007 financial crisis, real estate prices were soaring. Homebuyers were influenced heavily by the idea of the consumerist American dream, and were buying bigger houses and

${ }^{3}$ Kamp. David. "Rethinking the American Dream." Editorial Vanity Fair Apr. 2009. <http://www.vanityfair.com/culture/ features/2009/04/american-dream200904>

^Adams, James Truslow. The Epic of America. Boston: Little. Brown, and, 1931. Print 


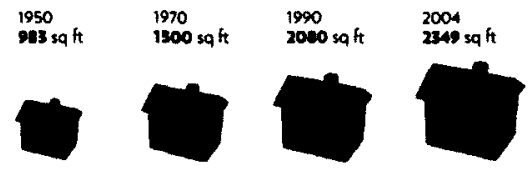

Fig. 3. Graphic representation of the increase in house sizes from 1950 to 2004. more square feet than ever before. Even many first-time buyers were convinced or lured into buying larger homes. The trend of larger homes had been evolving continuously over time, as average house sizes increased $140 \%$ since 1950.5 Home production had also increased to over one million new homes a year with over 110 million houses already existing in North America. ${ }^{6}$ It was on the assumptions that both high demand and increasing housing prices would persist, that the financial institutions continued dangerous lending practices that foreshadowed the financial crisis.

The financial crisis had a multi-layered effect on average Americans. First, and perhaps most important, was that many people lost their homes. How and why this occurred will be discussed later in detail; for now, it is important to note that, due to the 2007 financial crisis, a total of 14,076,512 homeowners lost their homes through 2012.? The second most important incident was that many people also lost their jobs. Due to the economic downturn, 7.9 million jobs were lost in the aftermath of the financial crisis. In addition, 54 million people, or 17.2 percent of the country, fall under the 'underemployment rate,' which MSNBC describes as 'part-time workers who want full-time jobs and laid-off workers who have given up their job hunt.' While this is an unfortunate reality, it marks an unprecedented problem that this study aims to turn into a positive opportunity through the recycling of the American Dream.

5 Information from the National Association of Home Builders for house sizes in 2009 and Greenbiz.com for House sizes in 1940 - Wilson. Alex and Jessica Boehland. Small is Beautiful: US House Size. Resource Use, and the Environment Greenbiz.com, 2005. Web.

- Friedman, Avi, and David Krawiz. Peeking through the Keyhole: the Evolution of North American Homes. Montreal McGill-Queen's UP. 2002. Print

" "National Real Estate Trends." U.S. Foreclosure Trends and Foreclosure Market Statistics. Web. 14 Oct. 2011. shttp:/l www.realtytrac.com/trendcenter/s.

8 7.9 Million Jobs Lost" CNNMoney. Cable News Network, 02 July 2010. Web. shttp://money.cnn.com/2010/07/02/ news/economy/jobs_gone_forever/indexhtm?.

- "Unexpected Drop in Jobless Rate Fuels Optimism." msnbccom. 04 Dec. 2009. Web. shttp://www.msnbc.msn.com/ id/34272155/\#.T30c8Y73h3t> 


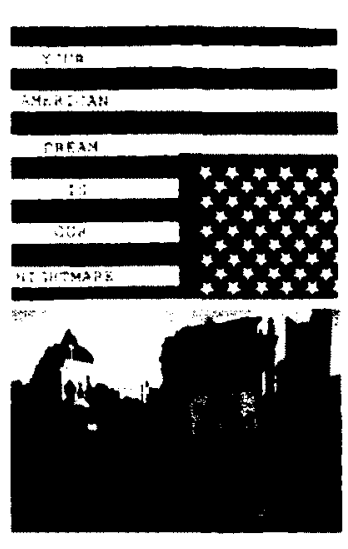

Fig 45. Your American Dreamis our Nightmare' poster. Unlrown date.

Protestors supporting the Occupy Wall Street movement. Sep. 2011.
The omnipresent idea of the American Dream unconsciously shapes the actions of millions of Americans and finds it roots perhaps in the genesis of the country itself. Written into the Declaration of Independence, the idea that the pursuit of happiness is an inalienable right of all Americans is proverbially woven deep into the American psyche. To prove that this dream still permeates American culture, one need only compare Jim Cullen's definition of the American Dream in his 2003 book The American Dream, A short History of an ldea that Shaped a Nation with the recent social protest movements Occupy Wall Street and the Tea Party:

That American Dream of a better, richer, and happier life for all our citizens of every rank, which is the greatest contribution we have made to the thought and welfare of the world. That dream or hope has been present from the start Ever since we became an independent nation, each generation has seen an uprising of ordinary Americans to save that dream from the forces which appeared to be overwhelming it ${ }^{10}$

By this definition, these political movements within the US clearly reflect this action. While supported by different sides of the political spectrum, both movements aim at defending each group's respective idea of the 'American Dream.' In the case of the Tea Party, a smaller, more fiscally conservative government; in the case of the Occupy movement, a more liberal, socially equitable society supported by the Government. In both these cases, hundreds of thousands of Americans share an idea of what they believe "America" to be, and by extension, share an ideal for the American Dream. The idea for defending the American Dream however, is seen more predominantly (or perhaps, more literally) during World Warll.

${ }^{10}$ Cullen, Jim. The American Dream: A short History of an Idea That Shaped a Nation. Oxford UP, 2003. Print. p. viii 


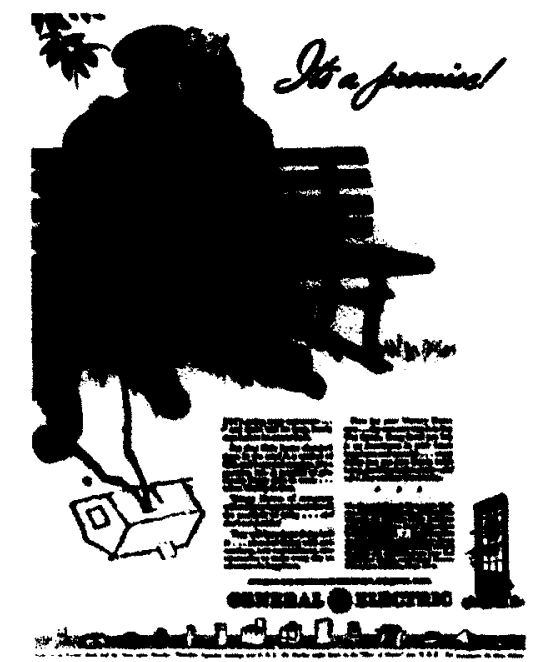

Fig. 6. Advertisement addressing needs of Veterans returning from the War. Chicago Tribune, 1947.
In the years during World War II, the American Dream was more than simply an ideological target for Americans to achieve. Instead it was used as a means to increase support for the war across the Nation. In effect, the idea of defending 'the American Dream' was used to recruit soldiers for the war effort, sell war bonds, and promote wartime jobs, such as production of war machines and ammunition in factories. This idea is also reflected by Cullen:

Truslow-Adams invoked it over thirty times in The Epic of America, and the phrase (the american dream) rapidly entered common parlance as a byword for what he thought his country was all about, not only in the United States but the rest of the world... the edition of the book I happened to pluck off the shelf at the Harvard College library came from a 1941 edition stamped as the property of an army educational supervisor stationed in Europe: The American Dream had become a weapon in the fight against Hitler. "

During the years immediately following the war however, these returning veterans, 'defenders of the American Dream;' couldn't afford the 'American Dream' or middle-class permanent housing. In both Canada and America, mortgage and lending corporations were developed by governments to ensure the possibility for home ownership, especially for veterans. In 1946 the Canadian Federal Government created the Canada Mortgage and Housing Corporation (CMHC) to help house the returning veterans, and in 1954, mandated this organization to provide mortgage loan insurance." Similarly in the US, the Veteran's Administration created the Veteran's Mortgage Guarantee Program in 1944, which allowed veterans to borrow the entire value of a home without any down payment. ${ }^{13}$ Both of these acts guaranteed war

"Cullen, Jim The American Dream: A short History of an Idea That Shaped a Nation. Oxford UP, 2003. Print p.4. 12 "History of CMHC.: Canada Mortgage and Housing. Web. shttp://www.cmhe-schl.gc.ca/en/corp/about/hi/ index.cfm>.

13 Jackson, Kenneth T. Crabgrass Frontier: the Suburbanization of the United States. New York, NY: Oxford UP, 1987. Print p. 219-245 


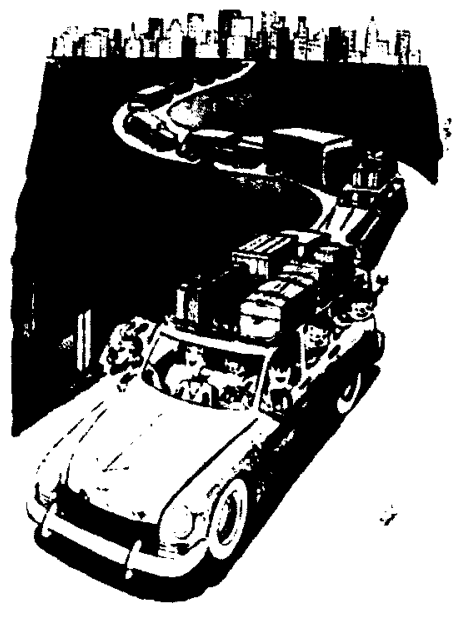

Fig. 7. 'Suburbia Cartoon.' 1957. Promoting the move out of the city and in to suburbia. veterans a loan for a house and ensured the lending banks were paid back as the loans were federally insured. There was no risk for the bank to loan money, so any veteran who desired to own a home was able to receive a loan to buy one.

Due to this ease of homeownership following the Second World War, the idea of owning a single family detached house became closely ingrained into the idea of the American Dream. For many, the modern or revived American Dream is just that - the idea of homeownership. Today, seventy years later, seventy percent of the American population still claims that owning a home is a key element in the American Dream.14 Forbes Magazine articulated its importance in our modern society:

It has symbolized everything from an investment opportunity, a career where money could be made easily, even a reflection of social status. Not one but two recent presidents ran on campaign promises to deliver affordable home ownership opportunities to all.15

To our modern society however, the American Dream has been heavily influenced by the ideas of consumerism. This influence can perhaps be traced to product advertisements. By their very nature, these advertisements aimed to convince consumers that their lives would be richer, or fuller through the acquisition of products, and subtly over time, consumers began to believe it. Perhaps then, it is not surprising that the first television commercial appeared in 1941, during World War II.6 Television advertising would become a potent tool in the influence of consumerism on the average American. Its emergence during this critical period, that is, the

14 Survey on Real estate website Trulia.com: shttp://info.trulia.com/indexphp? $5=438$ \&item=131>

${ }_{15}$ Brennan, Morgan. "Is The American Dream Of Home Ownership Dead? Not Really." Forbes Magazine, 11 Feb. 2011. Web. <http://www.forbes.com/sites/morganbrennan/201//02/11/is-the-american-dream-of-home-ownershipdead-not-really/>

16 "Bulova."Web. 21 Mar. 2012. shttp://www.bulova.com/en_us/legacys. 
war and post war period, dovetails with the re-emergence of the American Dream as it relates to home ownership, as seen with the returning veterans.

Without question in recent years, the American Dream and the idea of the pursuit of happiness' has evolved into the pursuit of material possessions. This idea has even been quantified in Professor Ted Ownby's 'Four Dreams of American Consumerism.'17 Today, the success of the American Dream is sadly measured by the value of the goods one has accrued. This unfortunate reality is perhaps best summed up simply by the then President Jimmy Carter, in his 1979 speech entitled, 'Crisis of Confidence,'

... too many of us now tend to worship self-indulgence and consumption. Human identity is no longer defined by what one does, but by what one owns. ${ }^{18}$

\footnotetext{
17 Reynolds, Jakob. "Today's 'American Dream' Too Focused on Material Happiness." The Daily Toreador. Web. 21 Mar. 2012. shttp://www.dailytoreador.com/opinion/article_cl7fcb58-43b1-11e0-bd8a-0017a4a78c22.htmls.

${ }_{18}$ Speech entitled 'Crisis of Confidence', delivered by former President Jimmy Carter from the Oval Office, July 15. 1979
} 
While the American Dream plays a major part in the current status of suburbia, another major aspect of understanding how suburbia evolved into its current form is urban and suburban design history. Major movements in architecture and urban design not only influenced how the suburbs are planned and constructed but also how they are perceived as both spatial and social entities. The understanding of these movements and their timeline allows us to see which aspects of suburbia were well executed, and how suburbia has changed and evolved over time.

\section{Cities are shaped in many ways. Economics, politics, society and culture all play crucial parts in}

this process. Whatever the forces and practices, cities are always the result of design."9

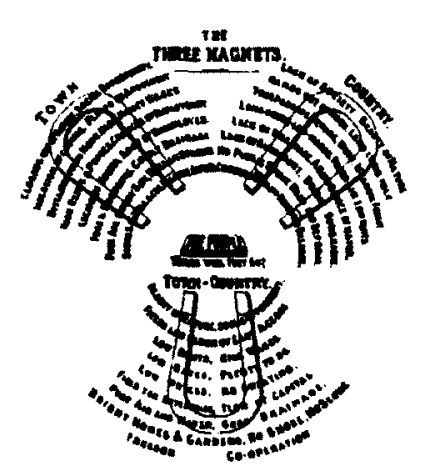

Fig. 8. '3 Magnet Diagram' created by Ebenezer Howard, addressing the question Where will people go? The 3 categories he includes are town, country, and towncountry.

Modern urban design would emerge as facets from multiple disciplines, perhaps first appearing from an art history standpoint in Camillo Sitte's 1887 book Urban Design according to Artistic Principles. In the book, he admonishes current city designs in comparison to those of Greek antiquity. Sitte was not interested in the historical context, or content of each building as an individual, and instead believed Urban spaces were 'intended to be lived in the now.' 20 Thus, it was the agglomeration of these buildings, streets-capes and facades into singular urban spaces that concerned him. His work is considered to be 'traditional' and 'formalist' within the urban design community. Many of the subsequent movements or theoretical works in urban design, such as Albert Brinckmann's The Art of Urban Design, published in 1920, are seen in response

${ }^{19}$ El-Khoury, Rodolphe and Edward Robbins. Shaping the City: Studies in History, Theory and Uiban Design. New York Routledge, 2004. Print

20 Collins, George Roseborough, Christiane Crasemann. Collins, and Camillo Sitte. Camillo Sitte the Birth of Modern City Planning. New York Rizzoli, 1986. Print. 

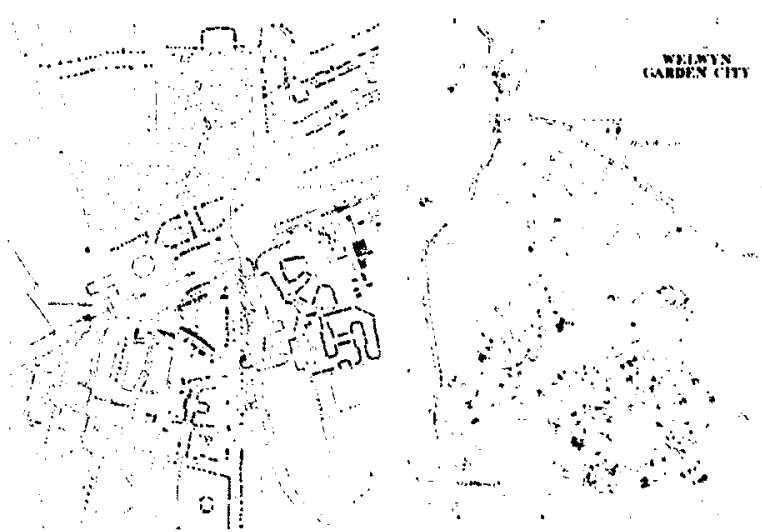

Fig. 9-10. Plan of Letchworth Garden City and Wehwyn Garden City

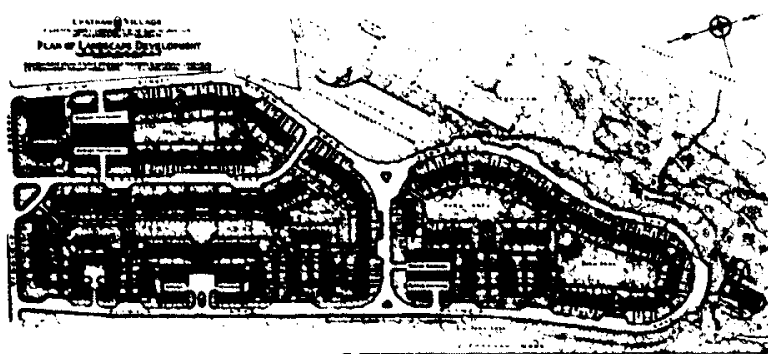

Fig. 11. Plan of Chatham Village, PA. Designed by Clarence Stein and Henry Wright, the plan shows the newly invented super-block. Chatham Village is known internationally as an acclaimed model of community design. to Sitte's assertions. The City Beautiful movement also emerged in this time period concurrently to Sitte's treatise (1890s - early 1900s). This movement, which centered on Washington D.C., Chicago and Detroit, was concerned with the beautification of urban centers. This was not only for the sake of beauty, but it was believed that it would instill a moral order and civic honor amongst urban residents. ${ }^{21}$

The next major point in Urban Design history would emerge in the UK from an Urban Planning standpoint, specifically in To-morrow: a Peaceful Path to Reform in 1898 written by Ebenezer Howard. This was the birth of the Garden City. Howard based his idea for the design of the garden city on the utopian novel 'Looking Backward', and intended the garden city to be the ideal (and utopian) living environment. ${ }^{22}$ Two garden cities in Hertfordshire, England were built in the on the ideals of the Garden City, Letchworth Garden City, and Welwyn Garden City. The influence of the Garden City in the United States was significant, with many examples of attempted garden cities sprinkled across the east coast. Chatham Village is possibly the most famous of these, built in the early 20th Century as a suburb of Pittsburgh, Pennsylvania by Clarence Stein and Henry Wright.

Around the same time Howard was proposing the idea of the Garden city, another major event occurred in 1927 that would have far reaching implications, not only in urban design, but also in architecture itself. Built as part of the Deutscher Werkbund exhibition in 1927, the Weissendorf exhibition would be the first and one of the most important exhibitions of what would later become the international style of architecture. It featured a great many architects who would later champion this style and spread it across the globe, such as Mies van de Rohe,

21 Hines, Thomas S. The City Beautiful Movement in America Urban Planning, 1890-1920. Journal of the Royal Institute of British Architects v.4, no.1 (1985): 28-43

22 Howard, Ebenezer. To-morrow: A Peaceful Path to Real Reform. London: Routledge, 1998. Print. 
Le Corbusier, Walter Gropius, Bruno and Max Taut, Hans Scharoun and J.P. Oud. Of particular interest to this study however, is the work of Bruno Taut. Taut would experiment with housing typologies and urban design to create massive housing complexes such as the Hufeisenseidlung, in Britz, a suburb of Berlin. These buildings were of such a large scale, they would constitute entire street-scapes, and their design and planning required urban level thinking. When several of these architects moved to America due to the outbreak of war in Europe, many of these urban design ideas would clash and influence subsequent American housing typologies:

In these works the older traditions of American philanthropic housing, apartment house layout. and Beaux-Arts planning ${ }^{23}$ collided with new ideas of housing developed by European modernists in the 1920s and introduced into this country just as the federal housing programs began.24

In 1956. Havard University would start a series of conferences that were instrumental in the development of urban design as a discipline within urban planning and architecture. By 1960 , the school created the first specific Urban Design program, even though it and other schools already offered City Planning. It would continue to spark discussion within the field which would culminate in 1961, a seminal year in the development of the theory of urban design. In this year, Jane Jacobs would publish The Death and Life of Great American Cities. It was a scathing criticism of what she termed 'rationalist' urban development and planning specifically

${ }^{23}$ Beaux-Arts was a neoclassical architectural style that was rooted in Parisian architectural academia. It's influence was seen in architecture in the United States in the period between 1880 and 1920 . Information referenced from: Klein. Marilyn W. David P. Fogle, and Wolcott B. Etienne. Clues to American Architecture. Washington, DC: Starrhill, 1986. Print. p.38

24. Pommer, Richard. The Architecture of Urban Housing in the United States during the Earty 1930s. Journal of the Society of Architectual Historians. Vol. 37. No. 4. California: University of California, Dec. 1978. 235. Print. 
in the 1950s. Jacobs claimed this type of urban development was killing inner city neighborhoods by disregarding the human component in their planning, instead relying on deductive reasoning to dictate the order of spaces.

Also in 1961, Kevin Lynch would publish The Image of the City which primarily dealt with concepts of legibility of urban spaces. He experimented with varying forms of urban representation, and proposed a type of 'mental map' to represent urban spaces as opposed to the two-dimensional master plans which had existed for the previous 50 years.

These releases, as well as others such as Learning from Las Vegas by Robert Venturi, Denise Scott-Brown, and Steven Izenour, and Christopher Alexander's A Pattern Language: Towns, Buildings Construction would contribute to the rise of New Urbanism in the 1980 s in the United States. This movement, which primarily targeted suburban design, was concerned with the promotion of walkability in neighborhoods, and the implementation of urban design teachings of theorists like Christopher Alexander and Jane Jacobs. Unlike the distant sprawl of modern suburbs, homes in new urbanist communities are not isolated. The goals of New Urbanism are stated within their charter:

We advocate the restructuring of public policy and development practices to support the following principles: neighborhoods should be diverse in use and population; communities should be designed for the pedestrian and transit as well as the car; cities and towns should be shaped by physically defined and universally accessible public spaces and community institutions; urban places should be framed by architecture and landscape design that celebrate local history. climate, ecology, and building practice. ${ }^{25}$

25 "Charter of the New Urbanism." Congress for the New Urbanism. Web. 05 Apr. 2012. 〈http.//www.cnu.org/charter>. 


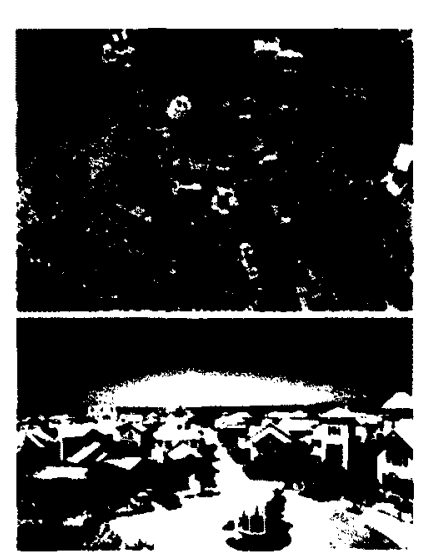

-...1-

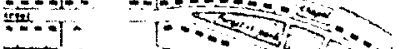
$-1=0.0 \%$

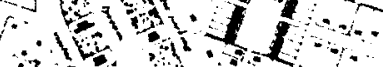

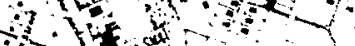
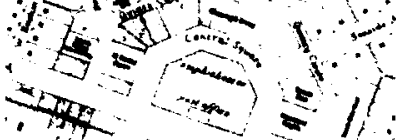

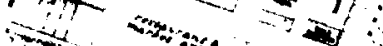

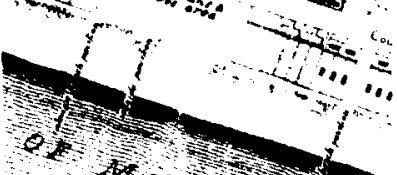

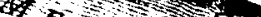

Fig. 12-14. Aerial view of Celebration, FL view of Seaside. FL and site plan of Seaside.

Due to the emphasis of walking rather than driving, residents of New Urbanist communities are able to interact with their neighbors more often, creating a social catalyst and fostering an important sense of community. This concept of community, championed decades ago by Jane Jacobs, now appears to be especially important to younger generations, and in turn, they are more than willing to manage with less square footage. This is due to New Urbanist houses generally lacking in the over-excess of 'McMansions.' The movement continues to gain traction today, with a few new urbanist communities built in America, such as Alys beach. Celebration, and Seaside, FL

While new Urbanist developments are heavily influenced by the writings of Jane Jacobs, she herself was staunchly opposed to mass produced suburbs, a fact she alluded to in the final chapter of her book The Death and Life of Great American Cities. Seeming strangely precognisant of many current attitudes toward suburbia she writes:

The semisuburbanized and suburbanized messes we create in this way become despised by their own inhabitants tomorrow. These thin dispersions lack any reasonable degree of innate vitality, staying power or inherent usefulness as settlements. Few of them, and these only the most expensive as a rule, hold their attraction much longer than a generation; then they begin to decay in the pattern of city gray areas.... Thirty years from now we shall have accumulated new problems of blight and decay over acerages so immense that in comparison the present problem of the great cities' gray belts will look piddling. ${ }^{26}$

Jacobs' stance on suburbia was echoed by other thinkers of the day. One such person was Lewis Mumford, a noted literary critic and American historian. In his book, The City in History. Its Origins,

26 Jacobs, Jane. The Death and Life of Great American Cities. New York Random House, 1961. 445. Print 
Its Transformations, and lts Prospects, Mumford decries the way in which suburbs are presented as the answer to urban housing problems, but are in fact, a hollow existence.

The cost of this detachment in space from other men is out of all proportion to its supposed benefits. The end product is an encapsulated life, spent more and more either in a motor car or within the cabin of darkness before a television set ${ }^{27}$

This type of thinking about the suburbs, sustained by influential thinkers such as Jacobs and Mumford, have endured in architectural discourse until the present day. However, so too has the suburban typology they eschewed. What this shows is while movements such as $\mathrm{New}$ Urbanism have attained some level of success, the modern suburban typology is not disappearing, despite its widely catalogued faults. This underlines the need for a different approach to dealing with the detrimental aspects of suburbia, that takes into consideration the reality of the continued existence of this typology. This new type of approach can perhaps be seen in the 2011-2012 project initiated by the Museum of Modern Art, entitled Foreclosed: Rehousing the American Dream. The project consists of 5 teams of mixed professionals which included Architects, Planners, Ecologists, Engineers, Landscape Designers and other Urban and Suburban specialists. These teams were responsible for proposing a series of comprehensive schemes specifically targeting ways of addressing suburbia and the sub-prime mortgage crisis through architectural interventions.

${ }^{27}$ Mumford, Lewis. The City in Histony. Its Origins, Its Transformations, and lts Prospects. New York Harcourt, Brace \& World, 1961. 509-12. Print. 
A number of factors in the period after the Great Depression and following World War II attributed to the rise of the suburban typology that we understand today. This suburban transformation, into what we currently call 'suburbia,' took nearly half a century to complete. In essence, three factors contributed to the rise of suburbia: the Government, veterans returning from the war, and the automobile.

The passing of the G.I. Bill in 1944 in many ways plays an integral role in the genesis of suburbia. It was originally drafted by Harry Colmery, a WWI veteran and Republican National Committee chairman, as the Servicemen's Readjustment Act.28 Many of the main benefits of the G.I. Bill were targeted at allowing and encouraging veterans to attend higher education institutions. However the most important of these benefits with respect to this study was the inclusion of guaranteed mortgages for returning veterans. These mortgages also contained a wealth of extreme incentives to ensure their usage, the most notable of which was there would be no down payment required. ${ }^{29}$ This resulted in droves of veterans moving out of their urban apartments and into suburban homes, creating a huge demand for this housing type.

Veterans were responsible for buying 20 percent of all new homes built after the war ${ }^{30}$

\footnotetext{
28 "United States Department of Veterans Affairs." Gl Bill's Histony - Born of Controversy: The Gl Bill of Rights. Web. <http://www.gibillva.gov/benefits/history_timeline/indexhtmb.

${ }^{29}$ Servicemen's Readjustment Act of 1944. P. 291-292. United States Statutes at Large. 58 Stat. 268.

30 "National Archives : Our Documents." Servicemen's Readjustment Act (1944). Web. 21 Mar. 2012. 〈http:/ www.ourdocuments.gov/docphp?doc=76>.
} 


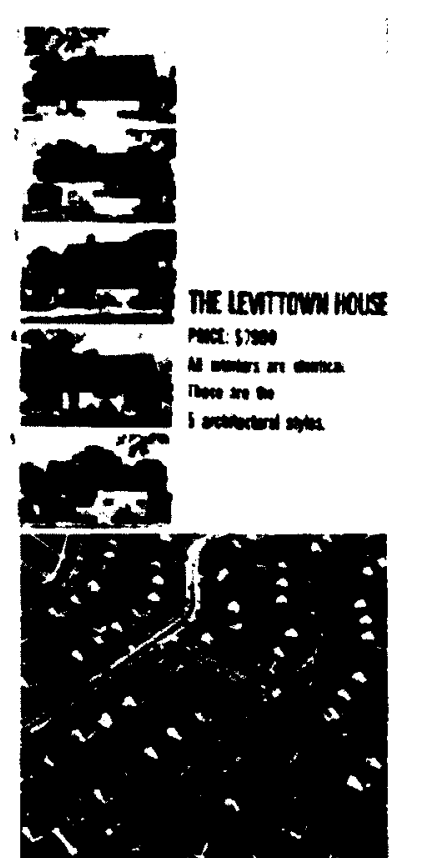

Fig.15-16. The 5 architectural styles offered for the Levittown House: Aerial view of Levittown, NY
The loans that were administered, however, came with several stipulations. The Federal Housing Administration (FHA) in the United States controlled the style and form of allowable housing. The FHA had been created in 1934 as part of the restructuring of the failed banking system, due to the Great Depression. It was founded in an effort to increase the numbers of home loans and home ownership. It was speculated that increasing home loans and thus home ownership was a key ingredient in successfully ending the depression. ${ }^{31}$

However, when coupled with the G.I. Bill, the FHA mandated that the home had to be between 6 and 8 thousand dollars (77-102 thousand adjusted for inflation) and be between 800 and 1100 square feet. ${ }^{32}$ These regulations resulted in vast numbers of houses that looked nearly identical.

The last major factor that allowed for the rise of the modern suburban typology was the automobile. The explosive rise of the automobile, specifically in the United States, revolved around the evolution and improvements of the assembly line made by Henry ford in the early 1900s. This efficiency allowed for an affordable car that all Americans could buy, and automobile registrations skyrocketed after the introduction of Ford's Model T. $\ln 1905$ there were only 8000 automobile registrations in all of the United States. By 1925, there were 17.5 million. Through 1945, the number had steadily climbed to 26.5 million, but in the 10 years following the war, the number almost doubled to 52 million. 33 The automobile was ubiquitous, as well as the evolution of the infrastructure which allowed for its expansion. By the late-1940s, with the end of the war, the availability of the automobile played a huge role in the genesis of suburbia.

31 The National Housing Act of 1934, Pub.L 84-345, 48 Stat 847.

${ }^{32}$ Friedman, Avi, and David Krawitz. Peeking through the Keyhole: the Evolution of North American Homes. Montreat: McGill-Queen's UP, 2002. Print.

${ }^{33}$ Jackson, Kenneth T. Crabgrass Frontier the Suburbanization of the United States. New York, NY: Oxford UP. 1987. Print. 

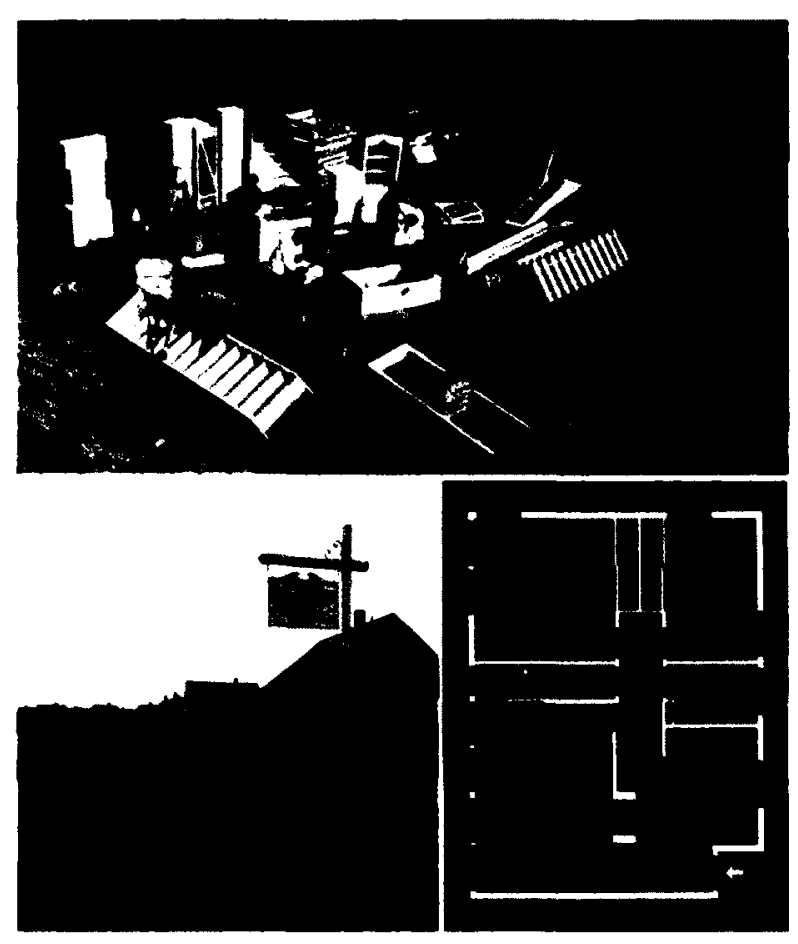

Fig.17. Pre- fabricated pieces of a typical Levittown house, arranged and in preparation for rapid construction

Fig. Newly completed levittown house.

Fin.19. Floor plan of a trical Leuse.

house. The house would be approximately

900 square feet and the square plon
These facets, the actions of earlier war veterans, the government founded FHA, the passing of the G.I. bill, and the availability of the automobile, all came together to form the first suburb of the modern-day typology: Levittown, New York It became the archetype for the modern suburban typology across the country.

The houses built in Levittown consisted of slab on grade wood frame bungalows, with simplistic designs and square floor plans to maximize space. Each house was built in about seven months, which was considered fast due to adaptations in building homes from industrialized processes ${ }^{34}$ In comparison, with current day construction methods, it takes about two months to complete an average home.

While, in the past several decades, the suburban house has evolved drastically, the typology of suburbia has remained relatively constant since the building of Levittown. Initially, people moved from the city centers to the suburbs, and they were soon followed by businesses, strip malls, big box stores, offices and parks. In the past few decades, while cities have gentrified, the suburbs have continued to grow at alarming rates. 


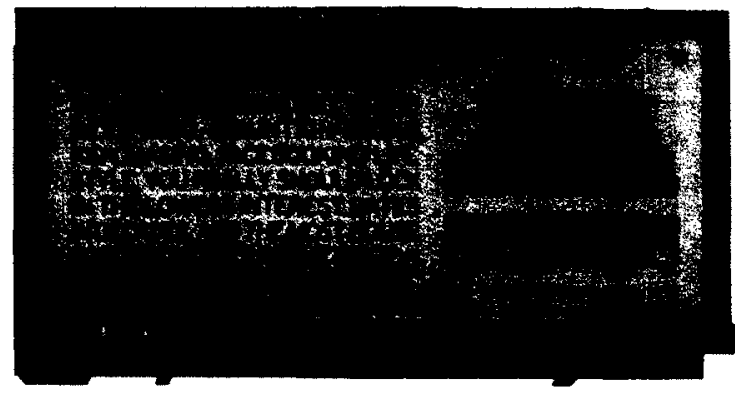

Fig.20. 'Got a big Life? Get a big house.' A billboard encouraging the purchase of a large house to store all of your possessions.
A look into 'The American Drearn' and consumer culture offers insight into the evolution of the post war suburban house, where the drive for bigger, faster and cheaper became the currency of value. When considering this excess in size, one need not look far to see how pervasive it has become across the lives of everyday Americans. It has reached a level where vehicles, food, and even people have become alarmingly large over a short period of the past few decades. It begs the question: If, over the past 60 years, family sizes have decreased, and there is more awareness of the world's diminishing resources, then why have house sizes increased $140 \%$ since 1950 ? ${ }^{35}$

One can develop a more thorough understanding as to why the average household has grown two and a half times in size over the past 60 years, by isolating specific areas of the home that have undergone the most notable transformations; the garage, kitchen, and storage spaces. The most extreme transformation, given our car-centric way of life, is the garage.

Garages are today deemed essential to the modern house, and comprise forty percent of its facade. Yet, when the program of this space is analyzed, one discovers oftentimes that it is used to store everything but cars. By storing extra things inside the garage however, the primary space for car storage shrinks, leading to even larger garages. Due to this accumulation, when two cars can no longer fit in a 2-car garage, 3-car garages are built, which are roughly 900 square feet, or the size of an average home built in $1950 .{ }^{36}$

\footnotetext{
${ }^{35}$ Busch, Akiko. Geography of Home: Writings on Where we Live. New York Princeton Architectural Press, 1999. ${ }^{36}$ Friedman, Avi, and David Krawitz. Peeking Through the Keyhole: The Evolution of North American Homes. Montreal: McGill Queens University Press, 2002
} 
[The garage's] revered status in the contemporary home surely has much to do with its role as sanctuary and shrine to the automobile. Our love affair with cars reflects a complex intersection of American obsessions, including those with machines, money, status and speed. ${ }^{37}$

Interestingly though, homeowners have been entering their houses through their garage for decades, yet, suburban homes continue to be built with grand front entrances that are rarely used. This is oftentimes due to nostalgia and historical precedent.

The next notable transformation within the suburban house is the kitchen. In looking at the history of the Kitchen, it is interesting to note the room's movement through time, within the plan of the house. During the mid-fifteenth century, the kitchen was the nucleus around which the entire house was designed: the chimney of the early fireplace was the dominant architectural feature of the home, and the hearth was its center. However, the status of the kitchen was reduced to merely a service room in the 18 th and 19th centuries, located in a separate room at the back of the house. This deviation in the position of the house is reflected in the socio-political climate of the era, cooking became a menial task, often performed by slaves or servants. As such, the position and status of the kitchen reflected this reality. Since then however, society has grown to celebrate cooking and view it as a sophisticated skill rather than a labor-intensive task.

Thus, the kitchen has returned to a dominant feature of the home. Nonetheless, the kitcheris primary role has grown into a social space more than a sevvice room to prepare food, which explains why this room has kept growing in size, despite the fact that families buy more preprepared food that require less use of the functional features of the kitchen. While considering this, it is interesting to note that the kitchen has doubled in size to 300 square feet. ${ }^{38}$

${ }^{37}$ Busch, Akiko. Geography of Home: Writings on Where we Live. New York Princeton Architectural Press, 1999.

${ }^{38}$ Busch. Akiko. Geography of Home: Writings on Where we Live. New York. Princeton Architectural Press, 1999 
Another notable transformation between the suburban house of the 1940's and one today is its storage spaces or closets. The floor plans of Levittown homes show the modest amount of storage space available to homeowners at the time ${ }^{39}$. Over the years of being influenced by consumerism however, the closet has first, grown in size, then developed into walk in closets or storage rooms, then into even bigger areas or storage 'floors' in basements and attics. Plenty of newly built homes now include two walk in closets adjacent to the master bedroom. In addition, closet organizers and other 'tools for living' were introduced, to allow homeowners to store more in less space. In a 1940s house, storage space of this magnitude would have been unimaginable, and perhaps entire rooms dedicated to storage would have seemed a ridiculous notion.

Our current day household is on average two-and-a-half times the size of an average home that existed only 60 years ago.38 The standard home size in the 1940s was a modest 950 square feet, whereas today, home sizes average about 2400 square feet. $\ln 2006$, the metrics for the average home were situated around a cost of $\$ 305,000$, comprising of four bedrooms, two and a half bathrooms and had a two-car garage. ${ }^{38}$ To put these numbers into context, the average home in the 1940's cost $\$ 89,000$ dollars, adjusted for inflation, was 950 square feet, had two bedrooms, one bathroom, and either no garage or a small one-car garage. These numbers become even more staggering when family sizes are taken into account, which have decreased almost $50 \%$ between 1940 and 2006.40

\footnotetext{
${ }^{39}$ See Figure 19. Page 17 for sample floor plans.

${ }^{40}$ Friedman, Avi, and David Krawitz. Peeking Through the Keyhole: The Evolution of North American Homes. Montreal
} McGill Queens University Press, 2002. 


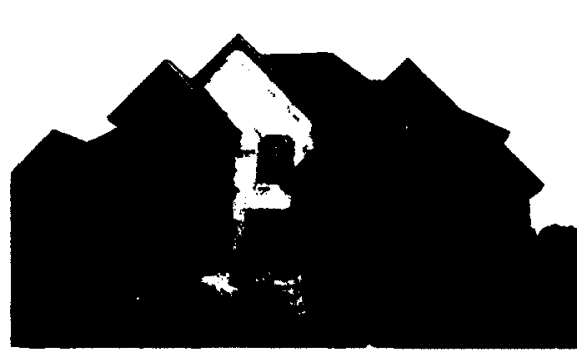

Fig.21. Typical McMansion under construction

As previously discussed, the principle of consumerism became a major part of the American Dream, and, by extension, influenced the evolution of the suburban home. This evolution, also previously discussed, generally warped the spaces within the home to be significantly larger. In essence, it was the demand for the ultimate 'consumer house' - that is, the biggest and most luxurious one could afford, that gave rise to what is currently referred to as the 'McMansion'.

The idea of the McMansion originated in the 1980's in California." It was intended to fill the void that existed between smaller suburban 'cookie cutter homes and large upscale custom homes that were unaffordable to most people. These larger homes proved popular in the 80 's and demand increased dramatically over the next 20 years. By the early 2000 s, entire subdivisions of houses, which were two and a half times larger than their 1940 predecessors, were being built at an alarming rate across the country.

The term 'McMansion' has no definitive origin. The 'Mc' prefix is meant to invoke associations with the speed and ease of production of fast food, and to connect this type of housing with the progression of consumer culture. The phrase 'McMansion' is referenced in a small book the mid-1980s, ${ }^{42}$ and can assumed to have been coined around this time. However, it didn't appear in mainstream media commentary until 1990.43

McMansions typically adhere to certain characteristics. They are generally over 3000 square feet, have two or more car garages, cover a large portion of the lot on which they are built, and have an

${ }^{41}$ Cecelia Techi. Exposés and excess: muckraking in America, 1900-2000. University of Pennsylvania Press, 2004. Pages 33-34

${ }_{42}$ Winn, Joni, Braces, Gym Suits, and Early Morning Seminary; A Youthquake Sunvival Manual. Salt Lake City: Covenant Communications, 1985. Print

${ }^{43}$ Hough, Michael. Out of Place: Restoring Identity to the Regional Landscape. New Haven: Yale UP. 1990. Print. 
inconsistent architectural style. These houses are often built as an entire community at a time by a single developer. ${ }^{44}$ The standard floor plans for McMansions are more formal than modern-day living needs, and often include many single-purpose rooms that are rarely used, such as large entry foyers, formal sitting rooms, and libraries.

These oversized homes, over time, have become the new symbol of the successful American Dream. That is, something that people aspired to have in order to feel successful in their lives and as a statement to others that they have reached a high level of success. However, the desire for a home of this magnitude is beginning to decrease:

The humble McMansion, the rightful reward of all hardworking Americans willing to take on a $\$ 450,000$ mortgage and a 75-minute commute in order to have a huge, useless foyer lined with the thinnest sheet of marble veneer, is no longer desired by the average homeowner, for builders who want to build homes that will actually sell. Shrines to conspicuous consumption are out! By necessity. 45

The 2007 Financial Crisis generally slowed the construction of homes across the country, specifically the construction of McMansions. This was due to the cascading effect foreclosures played in the American financial system (an issue discussed in a subsequent chapter.) However in 2006, a study completed by Arthur Nelson at Virginia Tech University regarding future demand of homes, forecasted 'a surplus of 22 million large-lot homes by year 2025. That's roughly 40 percent of the large-lot homes in existence today. 46 This statistic is made all the more dire, as the effects of the 2007 financial crisis are added to this surplus.

\section{${ }^{44}$ Stephen A Mouzon, Susan M. Henderson. Traditional Constnuction Pattems. MCGraw-Hill Professional, 2004.p. 144, 190}

45 Hamilton, Nolan. "The McMansion is Dead." Gawker. 2 Nov. 2011. Web. 21 Nov. 2011. shttp://gawker.com/5855598/ the-mamansion-is-dead?.

${ }^{46}$ Leinberger, Christopher B. "The Next Slum?" TheAtlantic. Mar. 2008. shttp://www.theatlantic.com/magazine/ archive/2008/03/the-next-slum/6653/\%. 
The subprime mortgage crisis is, in many ways, responsible for not only the current housing situation - that is, an unbelievable surplus of empty houses - but for the widespread disturbance of the entire global financial system. When viewed at a macro scale, this phenomena is interesting due to its far-reaching implications, which are still playing out today across the world. While the understanding of the crisis itself can become extremely complex, at its heart the cause is relatively simple and comes back to the idea of the American Dream. Only, in this instance, the target of the American Dream is twofold: the pursuit of wealth - on the part of the financial institutions, and the pursuit of a home - on the part of potential homeowners. It was the overlapping of these dreams that set the stage for the situation to occur. In many ways however, these financial institutions preyed on those whose dream it was to own a home, in pursuit of their own dream of wealth.

By the late 1990s, the dot-com bubble was in full swing, and many of the country financial institutions tied millions of dollars of investments into the booming industry. ${ }^{47}$ With its collapse in the early 2000s, alongside the September 11th terror attacks in 2001, Alan Greenspan, chairman of the Federal Resenve Banking System dropped federal interest rates down to $1 \%$ in an effort to keep the economy afloat and strong. ${ }^{48}$ What this meant was that investors, who would have usually bought Federal Treasury bonds as a safe investment, no longer did so given the low rate of return. On the other hand, banks could very easily borrow money from the

${ }^{47}$ Lowenstein, Roger. Origins of the Crash: The Great Bubble and /ts Undoing. New York Penguin, 2004. Print

${ }_{48}$ Shiller, Robert J. The Suborime Solution. Princeton. Princeton University Press, 2008. 44-49. Print. 

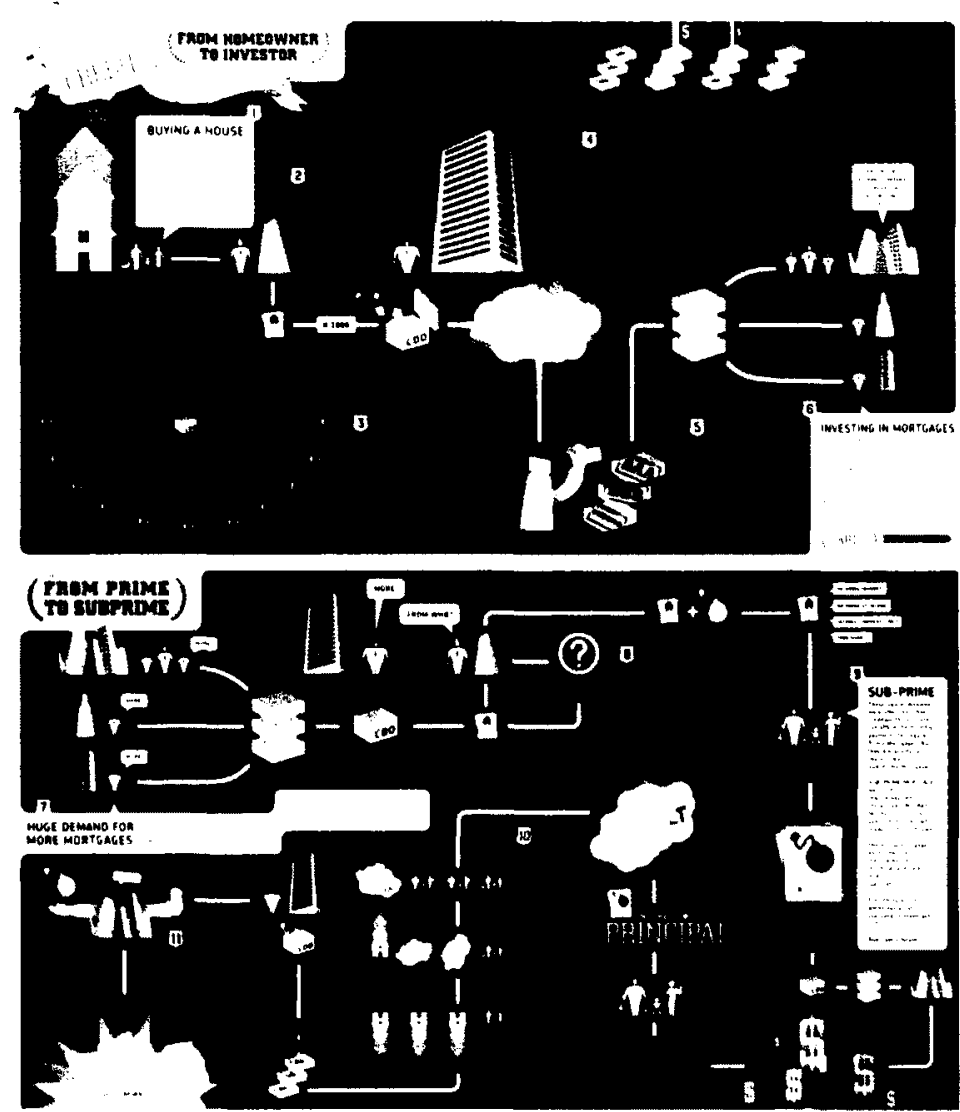

Fig. 22. Crisis of Credit Visualized. By Jonathan Janvis 2009. http://erisisofereditcom/
Federal Reserve to use as leverage to greatly inflate the outcome of their financial deals. Investors, who no longer had a safe investment in Federal Reserve Treasury Bonds, wanted a part of the profits that banks were reaping. Thus the financial system found a way to link investors who were searching for good investments, with homeowners, through their mortgages ${ }^{49}$

What transpired, was after issuing mortgages, mortgage lenders would sell them to investment banks. Using the cheap credit, investment banks were able to borrow vast sums of money in order to purchase huge numbers of mortgages. They subsequently packaged these mortgages, sliced them into three tiers of risk - AAA: Safe; BBB: Okay; Unrated: Risky - and repackaged them as Collateralized Debt Obligations (or CDOs.) This allowed the investment banks to sell each tier to other investors based on a certain level of risk (with matching increases in rates of return.) The investors had found the safe investments they had wanted at a reasonable rate of return, and during the early 2000 s, it worked out well for all involved. 50

The difficulty arose when investors asked for more CDO slices to invest in, even though most people who had qualified for mortgages already had one. Thus, mortgage lenders added risk to mortgages (such as no down payment and no proof of income) and arguably began predatory tactics in an effort to lure more potential homebuyers to receive mortgages, on the knowledge that they would sell the risk of the mortgage to an investment bank ${ }^{51}$ These loans, issued to more potentially delinquent homeowners, were called Sub-Prime loans, and carried higher interest rates than regular prime loans to compensate for the increased risk attached to them.

${ }^{49}$ The Crisis of Credit Visualized. By Jonathan Jarvis. Web. <http://crisisofcredit.com/s. Forbes.com Reuters Financial Blog, and NPR Planet Money have commended the simplicity and clarity of the video, as well as the attention to both macro and micro issues.

${ }^{50}$ Engel, Kathieen C., and Patricia A. McCoy. The Subprime Virus. New York Oxford UP, 2010. Print.

5) Schwartz. Herman M. Subprime Nation: American Power, Globa/ Capital, and the Housing Bubble. Ithaca: Cornell UP. 2009. Print 
Investment banks justified the added risk on the fact that housing prices had been increasing steadily for years. Thus, even if the homeowner defaulted on the loan, they could easily re-sell the house at the increased value. As a result, investors asked for more CDO slices. It all imploded however, once sub-prime foreclosures began to spread across the country in ever increasing numbers. ${ }^{52}$

These foreclosures occurred when the initial low period of interest (another predatory tactic designed to entice potential homeowners) attached to sub-prime mortgages expired. Homeowners were unable to refinance their homes and could not afford to make payments at this new interest level, therefore, defaulting on their loans. The cascade effect caused a huge over-supply of houses for sale, and housing prices plummeted. In addition, prime-loan holders who were paying high mortgages on a house now worth less than the mortgage, began 'strategic defaults'. That is, they chose to no longer make payments to the mortgage, and walked away from their investment in the homes.

Once the number of foreclosures began to increase, mortgage lenders began to lose vast sums of money. Additionally, investment banks and investors also began losing money, caused by the mortgages being spread throughout the financial system, due to the intricate chain of sales, re-sales, and CDOs. The chain reaction in the financial system caused the crash of Wall Street in late 2007 and 2008, and also caused a serious ripple effect across the global financial system, the effects of which are still playing out today. ${ }^{53}$

\footnotetext{
52 Engel, Kathleen $C_{\text {, }}$ and Patricia A. McCoy, The Subprime Virus. New York Oxford UP, 2010. Print. ${ }^{53}$ Engel, Kathleen C.. and Patricia A. McCoy. The Subprime Virus. New York Oxford UP, 2010. Print.
} 

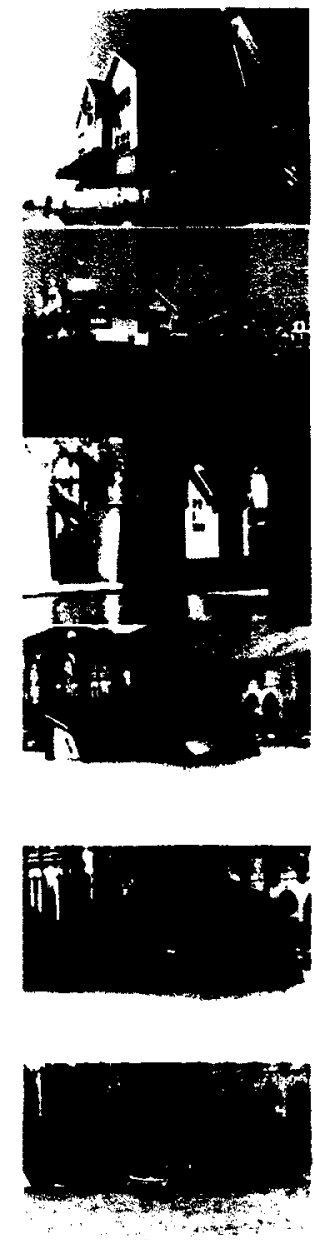

Fig. 23. Still Images from video: That sinking feeling: Venice shipwreck' exhibited at the 2009 Venice Biennale.

The Venice Biennale is a major contemporary art exhibition held every 2 years. In 2009, it became the site of the most unexpected but poignant commentary on the American housing situation. Artist Mike Bouchet had built a one-to-one scale replica of a typical American McMansion and intended to float it through the Venice canals. It was to be a monumental sculpture that embodied the American Dream. However, as the house floated across the Arsenale Basin to its resting place for the show, one of the pontoons holding up the house failed, causing the house to sink, entirely unexpectedly. Geoff Manaugh of BLDGBLOG sums up the irony of the project:

...the sight of the oversized house, clad in beige viny!, flimsily bobbing up and down against a backdrop of palazzi and piazzi as it was towed through Venice's canals, was breathtaking. It was an architectural icon of the American Dream revealed in all its formulaic absurdity.

Amazingly, then, one of the pontoons capsized, and the entire house sank to the bottom of the canal-an unintentional yet utterly perfect coda to the house's own built-in commentary. Now, a fake generic American suburban home will add its ruins to the underwater archaeology of Venice. ${ }^{54}$

This is perhaps the perfect example of what happened to many families during the foreclosure crisis, which lead to the financial crisis as previously discussed. Somewhat suddenly, families

\section{Manaugh, Geoff. 'BLDGBLOG: Watershed Down. BLDGBLOG. 9 June 2009. Web. <http://}

bldgblog.blogspotca/2009/06/watershed-down.html?. 

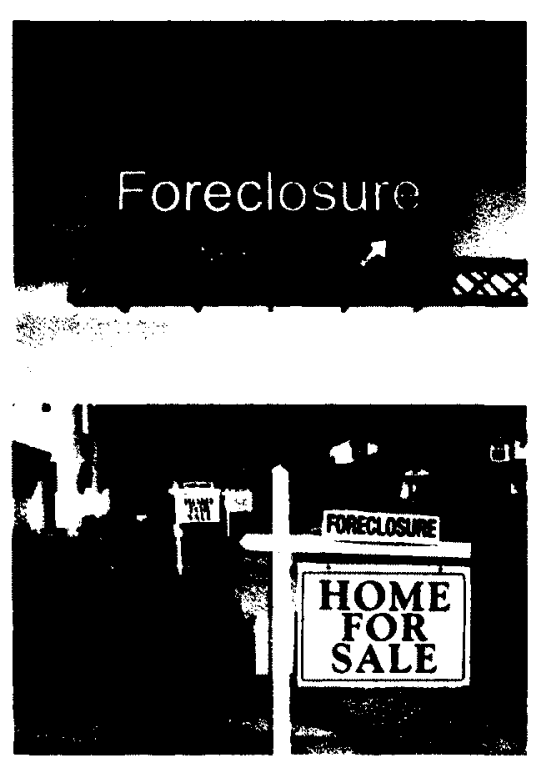

Fig. 24. Figurative Sign of foredosure at nearest exit Fig. 25. A common sight in many of America's neighbourhoods: Foreclosure signs on front properties. Often times, several will appear on the same street. found themselves financially underwater, drowning in their own mortgages, unable to do anything but default on their loans. Their American Dream had turned into an American Nightmare.

These foreclosures especially affected those living in McMansions. Many of the homeowners who lived in McMansions would not have qualified for loans large enough to pay for houses of that size. However as previously discussed, the tandem of the 'American Dream' driving consumers for bigger and bigger houses, and predatory financing tactics on the part of mortgage lenders, put these individuals in these oversized houses. When the Federal Reserve Bank raised interest rates to $5.25 \%$ from $1 \%$, home values instantly stagnated. This meant many of those sub-prime mortgage holders could not refinance their homes, based on an increased value of their property. This also meant many of them with Adjustable Rate Mortgages, which were tied to federal interest rates, now had to pay an even higher interest rate, once the low interest period of their loans expired. As also previously discussed, this caused a chain reaction that resulted in even prime-loan holders walking out on their properties, choosing 'strategic defaults' over paying back an inflated loan. Between the sub-prime mortgage defaults, and strategic defaults, a staggering number of foreclosed homes became available across the nation.

According to the Mortgage Bankers Association, every 3 months 250,000 new families have entered into foreclosure. Every 10 seconds, a foreclosure notice is filed $\$ 5$ In addition, the Realty Trac Press release market report states that at the start of the crisis, in Q1 2007, 239,770 homes entered into foreclosure. This number reached a high in Q3 2009, jumping to a

55 "Facts on Foreclosure." Federal Deposit Insurance Corporation. Web. swww.fdic.gov/about/comein/files/ foreclosure_statistics.pdf). 
US. Properties with Foreclosure Activity

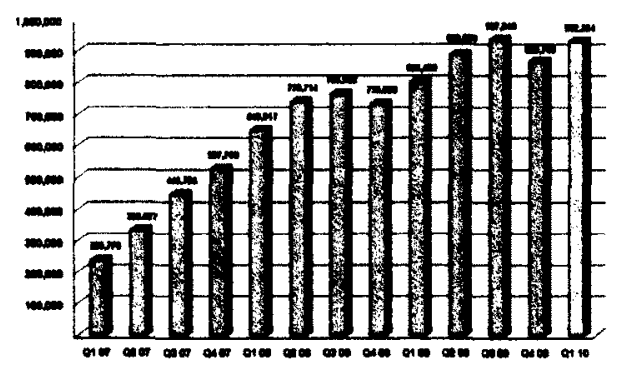

Fig. 26. Numbers derived from Realty Trac and money.CNN.com staggering 937,840. It remained relatively constant through 2010. As mentioned earlier, the total number of foreclosure filings to date is $14,076,512.56$

While high foreclosure numbers persist, homes are still being built at a surprising pace in certain regions. To put into perspective how quickly houses are being constructed, over 110 million homes currently exist in the US and Canada, with over 1 million new homes built every year. One quarter of all houses are inhabited by a lone occupant. ${ }^{77}$ This vast number is largely due to the fact that 70 percent of US citizens still claim that owning a home is a major part of the American Dream. In the article The Next Slum, by Christopher Leinberger, he states:

U.S. Census data projects there will be approximately 4 million more households with children in year 2025 than there were in 2000 and more than 10 million new single-family homes have already been built since 2000, the majority of them of course in the suburbs. As much as half of all real-estate development on the ground in 2025 will not have existed in $2000 .{ }^{58}$

In addition, the social impact of the foreclosure crisis was also very heavy for homeowners and neighborhoods. Crime became a major factor in the lessening of home values across neighborhoods, due to the abundance of empty homes from which criminal activity could be based. In a case study done in the suburbs surrounding Chicago, the findings state:

Homes in foreclosure that become vacant provide sites for crime or other neighborhood problems. One foreclosure can impose up to $\$ 34,000$ in direct costs on local government

56 "National Real Estate Trends." U.S. Foreclosure Trends and Foreclosure Market Statistics. Web. 22 Mar. 2012 shttp://www.realtytrac.com/trendcenter/s.

57 Friedman, Avi, and David Krawizz. Peeking Through the Keyhole: The Evolution of North American Homes. Montreat McGill Queens University Press, 2002.

58 -Leinberger, Christopher B. 'The Next Slum?" The Atlantic Mar. 2008. shttp://www theatlanticcom/magazine/ archive $/ 2008 / 03 /$ the-next-slum $/ 6653 / 2$. 
agencies, including inspections, court actions, police and fire department efforts, potential demolition, unpaid water and sewage, and trash removal.59

The New York Times also weighed in on this problem in Chicago in 2011, showing the issue persists as foreclosure numbers remain high.

The empty buildings are magnets for gang activity, depressing the value of nearby properties. Drug abuse violations and burglaries are the most common crimes taking place in abandoned

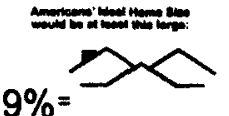
3200 squeres toot

$13 \%=$
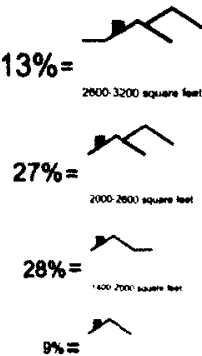

Fig. 27 The majority of Americans ideal home sire is between $1400-2000$ square feet. The current average house size in feet properties, police report. In Austin, [a suburb of Chicago,] burglaries and illegal drug use make up 74 percent of the 66 incidents reported in the past three months. ${ }^{60}$

The biggest question then, after hearing these statistics, is the crux of this study. What do we do with this surplus of empty homes? Especially the McMansions, as the taste for oversized homes dwindles and more sensibly sized homes begin to rise in demand. Some of these homes are large enough to serve as small grocery stores, office complexes, daycares, small schools, etc. In addition, by combining a number of these foreclosed or abandoned homes, one could house larger and more complex programmatic spaces for greater benefit to the surrounding community. Also, through 'repurposing the McMansion;' one could save money through the adaptive reuse process while improving the social landscape of suburban environments. This study will turn to the already existing solution of adaptive reuse, which is widely used within urban contexts and reapply it within a suburban environment.

${ }^{59}$ Apgar, William C and Mark Duda, and Rochelle Nawrocki Gorey, The Municipa/ Cost of Foreclosures: A Chicago Case Study Print. February 27, 2005

${ }^{\infty}$ Knight, Meribah, and Bridget O'Shea. "Foreclosures Leave Pockets of Neglect and Decay." The New York Times 27 Oct 2011. Web. shttp://www.nytimes.com/2011/10/28/us/foreclosures-lead-to-crime-and-decay-in-abandonedbuildingshtml?pagewanted=all? 


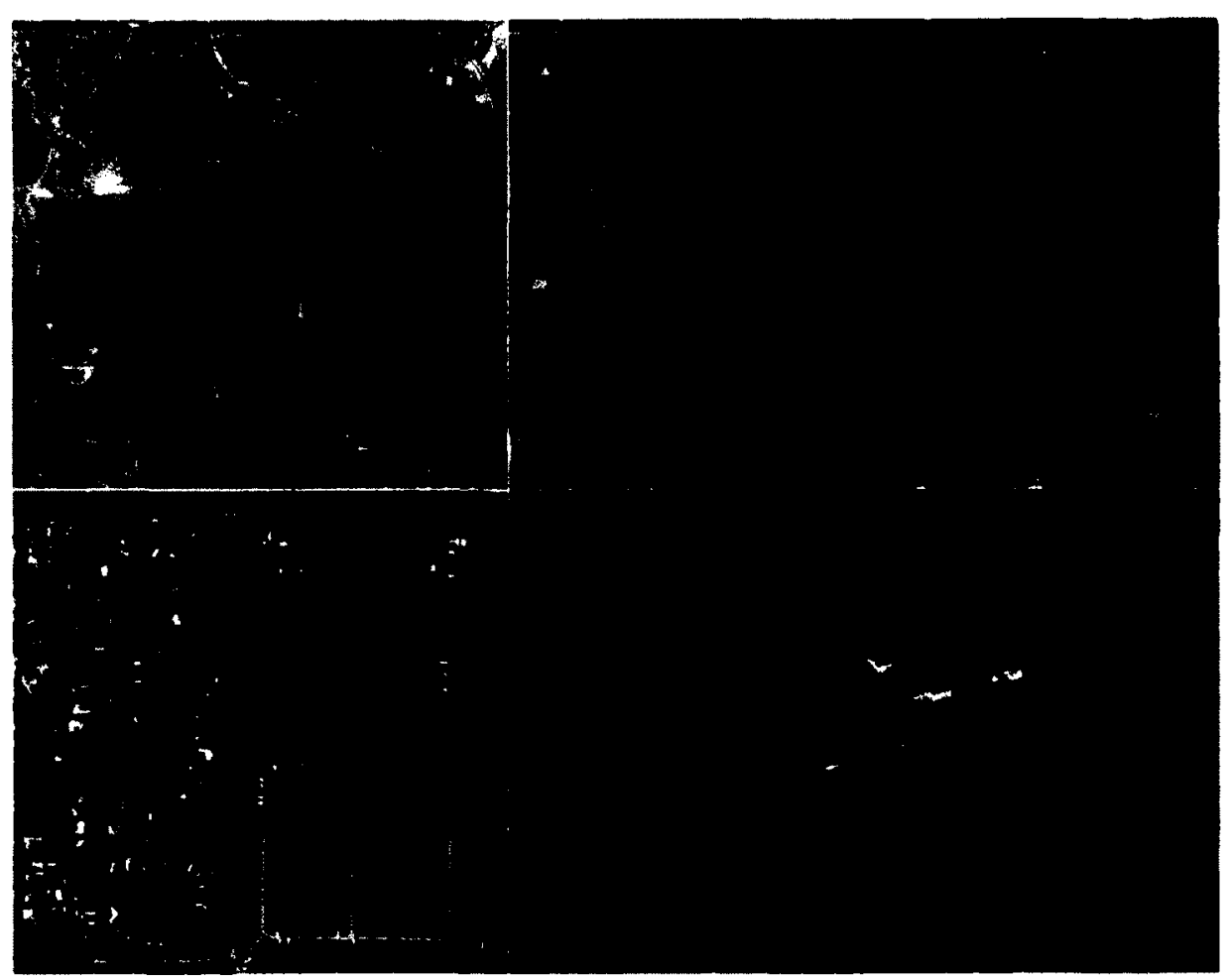

Fig. 2B. As developers across the country file for bankruptcy many suburbs stand unfinished. Top left: C.alifornia City. CA, top right. unknown, bottom left SW Florida, bottom right. Rio Vista. CA. 
A CASE STUDY. Repurposing the MCMansion +

Re-thinking the American Dream

\section{SITE + CONTEXT OF CASE STUDY}

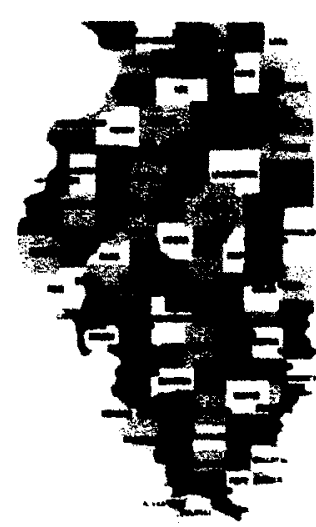

Fig, 29. Location of Will + Kendal counties in llinois.
In terms of rates of foreclosure, the state of lllinois is home to several of the hardest hit regions in the United States. While the media often refers to California and Florida as having the most extreme numbers of foreclosures, the numbers from llinois closely follow, putting it at third worst in the country. This is perhaps due to the fact that Illinois had some of the country's fastest growing towns and communities prior to the subprime crisis. The Chicago region, in particular, was heavily affected. Between 2000 and 2010 over 200,000 people had left the city and surrounding area. ${ }^{61} A s$ is the case with the foreclosure crisis, the outlying suburban regions of city centers were the most affected.

The hardest hit counties in Illinois are Will and Kendall Counties, both of which are suburban and exurban developments of Chicago. Kendall County experienced the most rapid development in all of the United States between 2000 and $2007 .^{62}$ Today, several of the subdivisions in these two counties remain unfinished as developers have gone bankrupt, and a significant portion of these freshly built houses stand empty.

\footnotetext{
61 "Chicago's Population Drops 200,000." Chicago Tribune. 15 Feb. 2011. Web. 18 Mar. 2012. «http:// articles.chicagotribune.com/2011-02-15/news/ct-met-2010-census-20110215_1_census-data-collar-countiespopulation>.

62 Johnson, Dirk. "Briefly the New Frontier, Exurbs See a Bust After Boom." The New York Times. 20 Aug, 2011. Web.

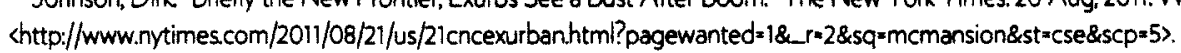



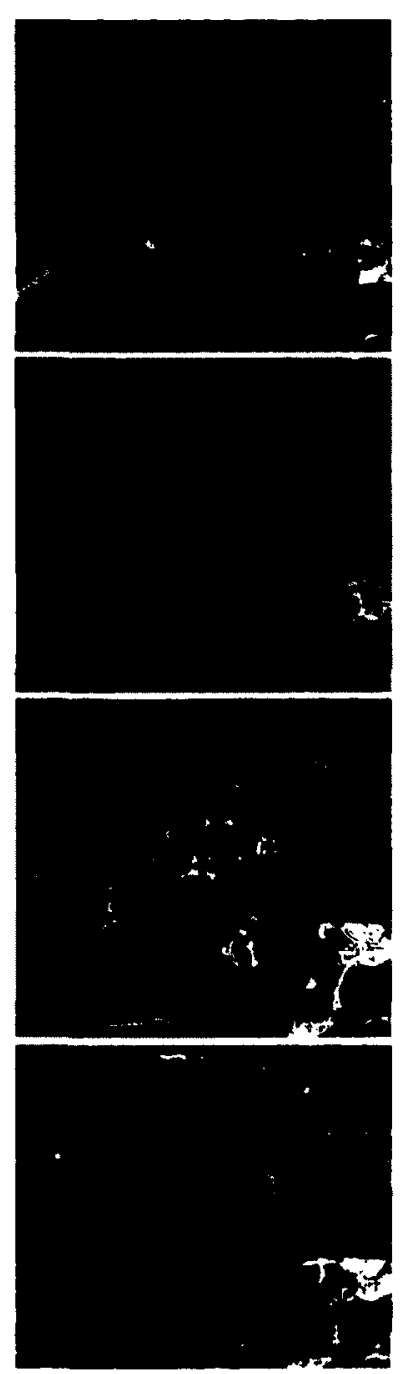

Fig. 30. Aerial View of the incomplete Foxidge Farms subdivision. In 1998 . Farm land dominated the area. Construction begari in 2002. and contmued through 2005 The ared remains as it is in the las image, in 2003. as the developer filed for bankruptcy
Population values in Chicago and closer suburbs have suffered, but distant areas were more vulnerable, because they were largely driven by speculation, as buyers bet on rampant growth. ${ }^{03}$

After studying official foreclosure statistics, proximities of foreclosed homes to each other, surrounding amenities, and neighbourhood development histories, an appropriate location for this case study was determined to be Bolingbrook in Will County, lllinois. Bolingbrook is a modern suburb of Chicago, a twenty-five minute drive from the city Centre. In Bolingbrook, 1 in every 125 houses are in foreclosure, compared to the national average of 1 in every 637. [2012] $]^{64}$ While Bolingbrook is located in Will county, it's proximity to Kendall County was seen as significant as it may have been viewed as one of the up and coming neighbourhoods during the construction boom. The particular community selected in Bolingbrook was Foxridge Farms. This was, in part, due to it being a community of McMansions, with each house averaging over 3500 square feet in size. In addition, the community has at least ten foreclosed homes, all of which are within close proximity to each other.

The Foxridge Farms subdivision was developed by Kimball Hill Homes, who were founded in 1969. During the height of the housing boom in the early 2000s, they were one of the 10 largest developers in America. Their developments were concentrated in what are now the country's most affected regions; California, Florida, Illinois, Nevada and Texas. ${ }^{65}$ Almost fittingly, Kimball Hill Homes filed for chapter 11 bankruptcy in December 2008, and halted all remaining construction, leaving numerous developments (including the Foxridge Farms subdivision) incomplete.

\footnotetext{
${ }^{63}$ Johnson, Dirk "Briefly the New Frontier, Exurbs See a Bust After Boom." The New York Times. 20 Aug, 2011. Web. <http://www.nytimes.com/2011/08/21/us/21encexurban.html?pagewanted=1\&_r=2\&sq=mcmansion\&st=cse\&scp=5>.

${ }^{\$} 2012$ Statistic. "National Real Estate Trends. "U.S. Foreclosure Trends and Foreclosure Market Statistics. Web. 27 Sep. 2011. shttp://www.realtytrac.com/trendcenter//

65 "Kimball Hill Homes." Articles about. Web. <http://articles.chicagotribune.com/keyword/kimball-hill-homes〉.
} 


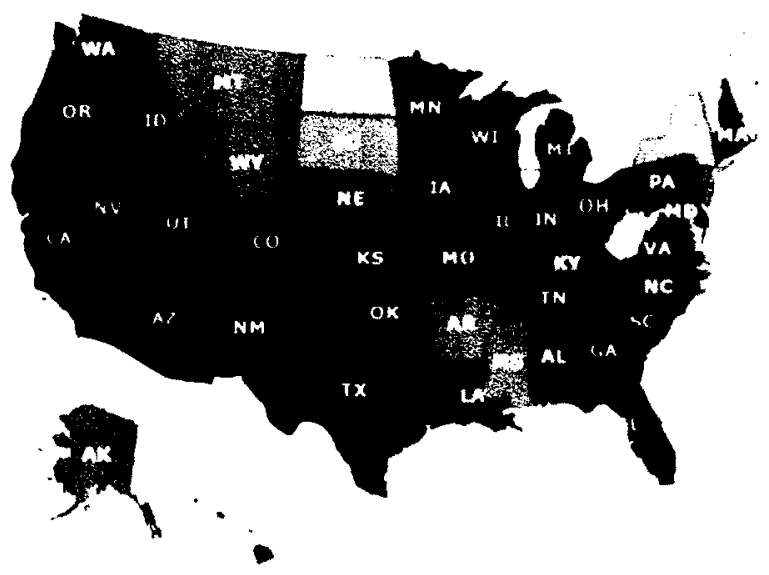

FORECLOSURE ACTIONS TO HOUSING UNITS - FEBRUARY 2012
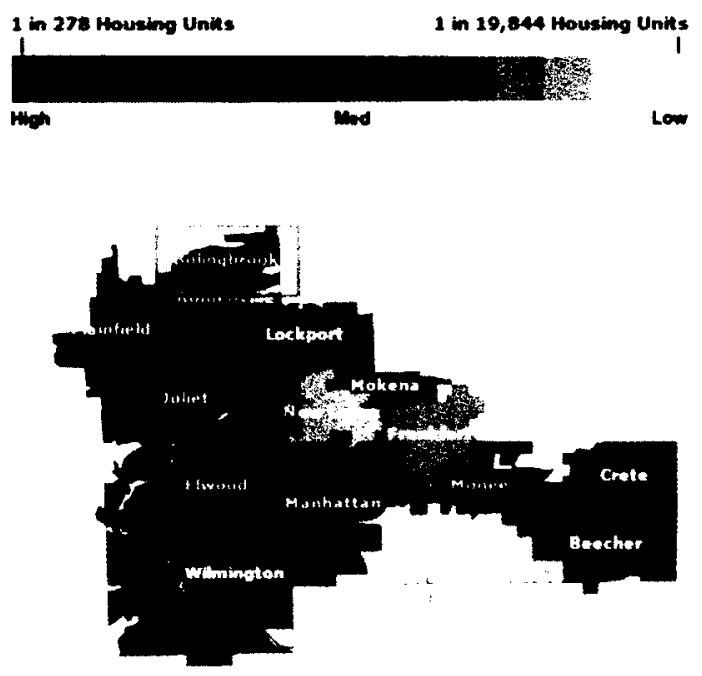

FORECLOSURE ACTIONS TO HOUSING UNITS - FEGRUARY 2012

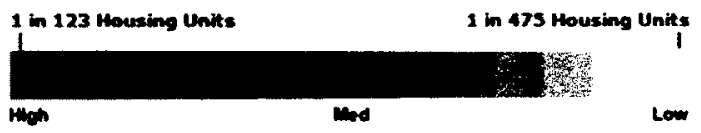

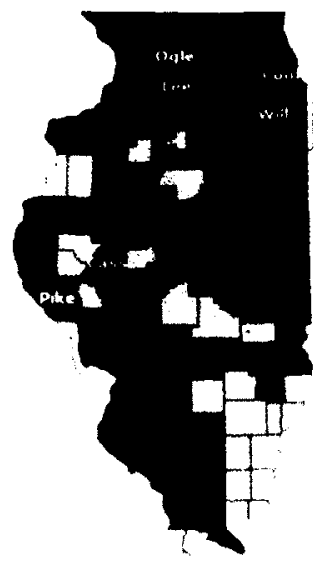

FORECLOSURE ACTIONS TO HOUSING UNITS - FEBRUARY 2012
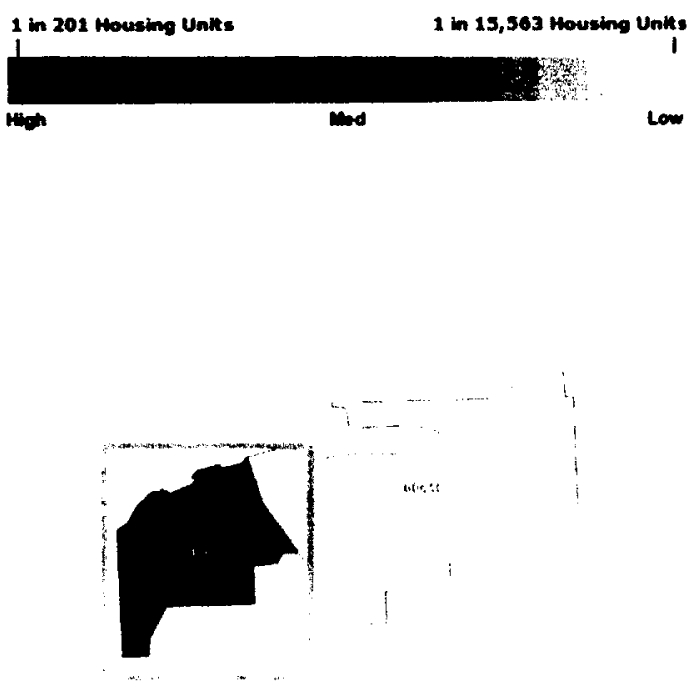

FORECLOSURE ACTIONS TO HOUSING UNITS - BOLINGRROOK

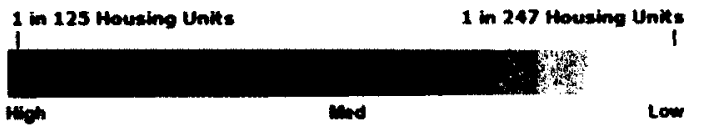

Fig. 31. Site of Case Study. demonstrating the severty of the foreclosufe crisis in the selected area. Information gathered form hitp/h wwwrealy,traccom/trendcenterf 


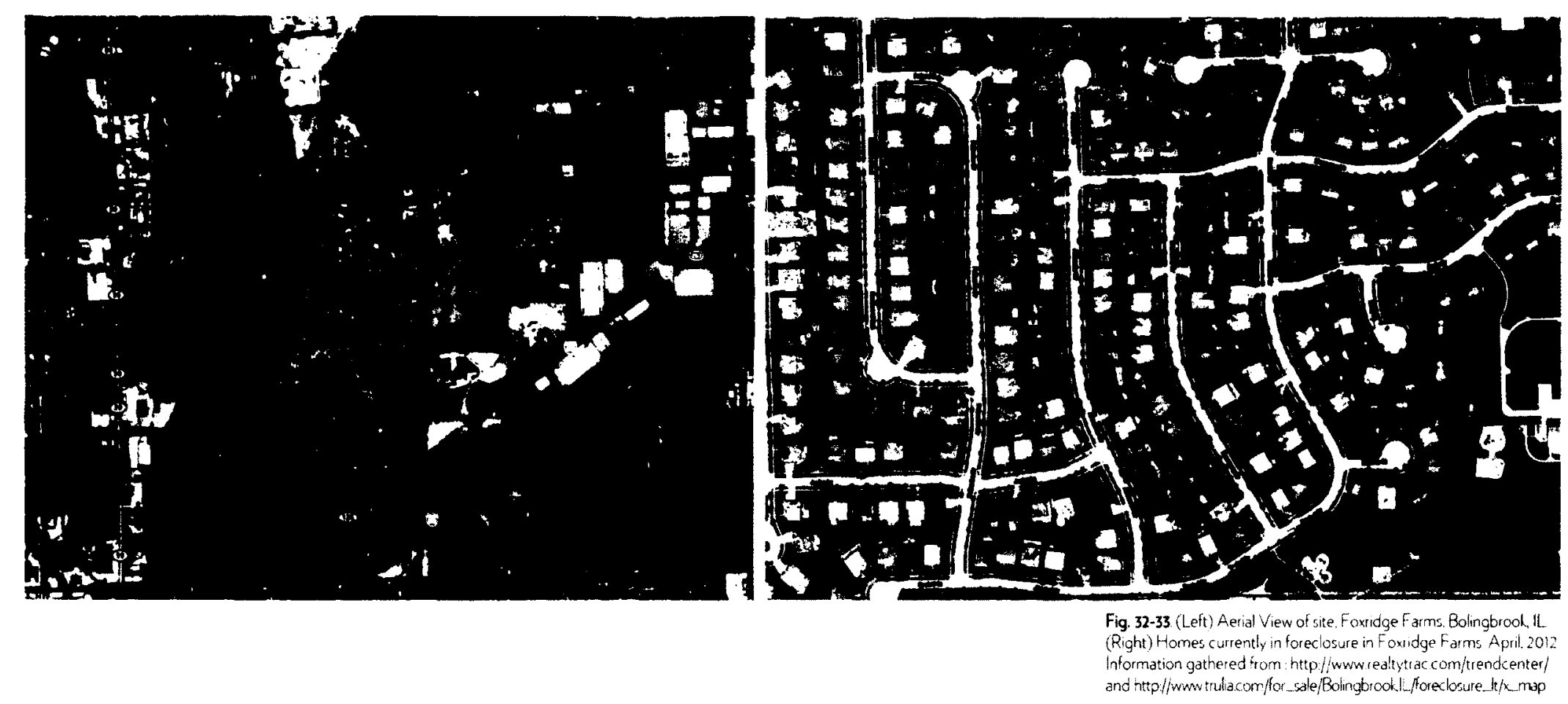


Prior to determining the specific houses that would be repurposed for this case study, a set of criteria was set to help with the selection process. This was necessary so as to clearly define, from the abundance of foreclosures in the area, which houses were best suited for repurposing. To support the types and scales of programs that would be housed in the structures, the foreclosed homes would need to be of a particular size. As the majority of the homes in the area fall into the 'McMansion' category, the size deemed appropriate for the case study was combined (floor + basement) 5500 square feet. The repurposed houses should also ideally be some distance away from amenities that are needed on a daily basis: i.e., grocery, convenience store, shopping center, etc. This criterion was chosen for two reasons. The first was a more social target, to encourage walking over driving. Thus, the repurposed home should be in shorter walking distance than driving distance to the nearest large-scale consumer center. The second reason was economic. The continuing survival of the newly created, locally run businesses would be critically handicapped if they were to directly compete with large scale retailers. The final criterion was that the selected homes must be located within a moderately dense suburb, promoting continued use of the building. These would have a myriad of positive effects for the neighbourhood, including the creation of jobs and space for work, social interaction amongst community members, and environmental advantages resulting from reduced car trips per day, to name a few. 
4:

!

$-\vdots 1$

,

!
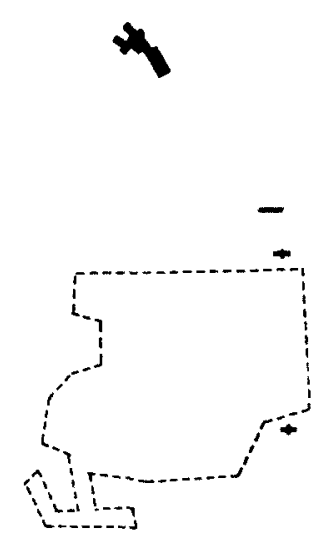

SUBURBIA REDUX / Recyling the Imerican 1) rean s.

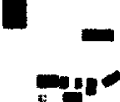

:.1.

$-\pi$

- I

- BIG BOX

- CONVENIENCE

GROGERY

- FAST FOOD

- apPARRel

- gank

- pharmacy

RESTAURANT
GYM

- GYM

- HOTEL

- DAY CARE

- SPA

Fig. 34. Amenities Map of area surrounding Foxidge Farms subdivision (located in dotted area.) Lighter areas depict residential areas. 


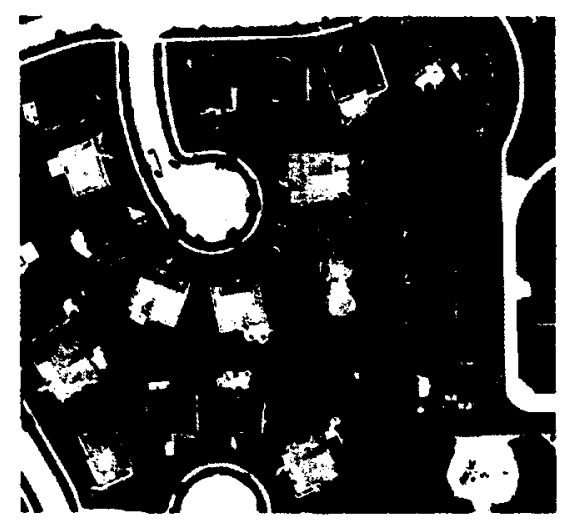

Fig. 35 1.2, and 3 Emily Court, Bolingbrook, IL 1 Emily Cour berry the northerl most house
Of the foreclosed houses studied in Foxridge Farms, three were of particular interest for use in this study. 1, 2, and 3 Emily Court, Bolingbrook IL, 60490, are all currently in a state of foreclosure and are located side by side around a cul-de-sac. This arrangement allows the opportunity to join the houses together, thus providing usage of the interstitial space between them, as well as an enhanced front and back yard. In addition, they are within walking distance of an elementary school. This was seen as a factor that could potentially increase foot traffic to the new building, or even encourage families to walk their children to school.

The Specifications of 1,2,and 3 Emily Ct, Bolingbrook, 1L, 60490 are as follows:

\begin{tabular}{|c|c|c|}
\hline $\begin{array}{l}1 \text { Emily } C_{t}- \\
\text { Winsford II model }\end{array}$ & $\begin{array}{l}2 \text { Emily } C_{t}- \\
\text { Winsford model }\end{array}$ & $\begin{array}{l}3 \text { Emily } C_{t} \text { - } \\
\text { Wexford model }\end{array}$ \\
\hline $\begin{array}{l}\text { Built } 2002 \\
3940 \mathrm{sq} f \mathrm{ft} \\
+3000 \mathrm{sq} \text { ft basement } \\
4 \text { Bdrm. } \\
2.5 \text { Bath }\end{array}$ & $\begin{array}{l}\text { Built } 2002 \\
3930 \mathrm{sq} \mathrm{ft} . \\
+3000 \text { sq ft basement } \\
4 \text { Bdrm. } \\
2.5 \text { Bath }\end{array}$ & $\begin{array}{l}\text { Built } 2004 \\
3544 \mathrm{sqft} \\
+2160 \mathrm{sq} f \mathrm{ft} \text { basement } \\
4 \text { Bdrm, } \\
2.5 \text { Bath }\end{array}$ \\
\hline
\end{tabular}

Each house is comprised of a family room, garage, four bedrooms (1 master) kitchen, dining room, breakfast room, den and a super great room. 

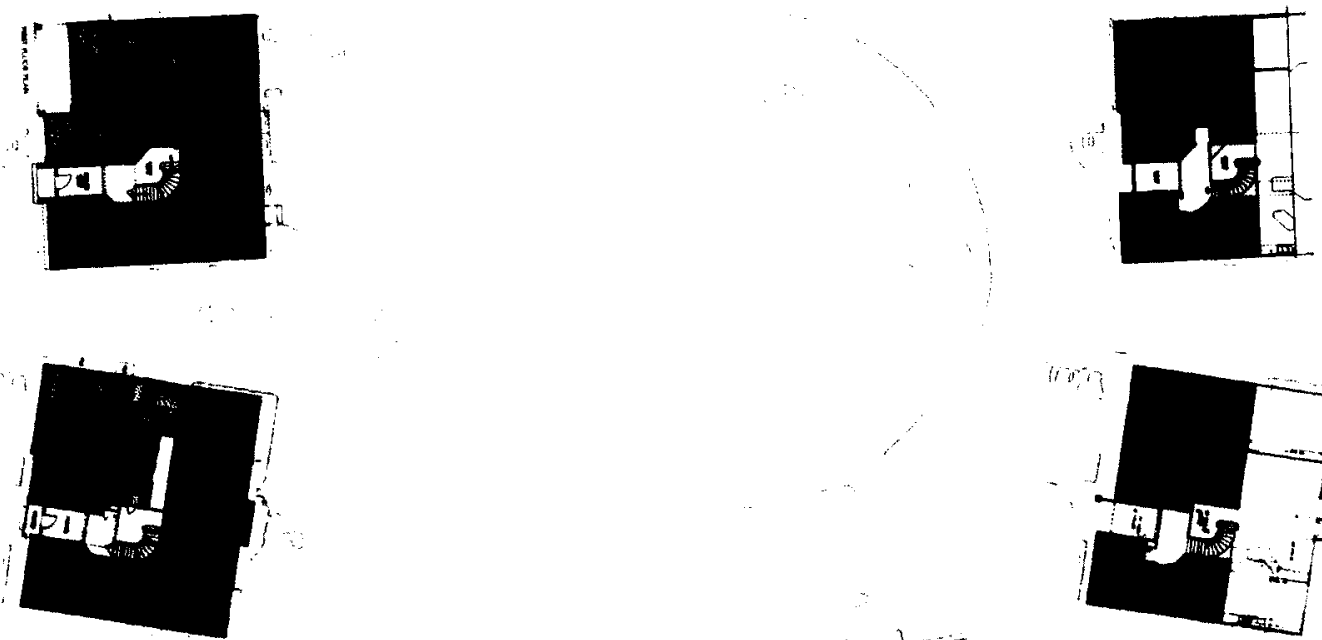

- SLEEP
- LIVE
DINE

D COOK

- STORE $/$ MECH

bath

CIRCULAT

garage

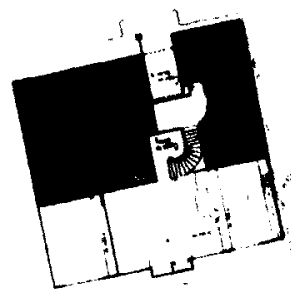

- SLEEP

- LIVE
- DINE
- COOK

- COOK
- STORE / MEC

STORE/MTOH

CIRCULATE

- work

Fig. 36. Progiam studies of existing floor plans of the foreclosed houses to be used in the case study Basement level not show 


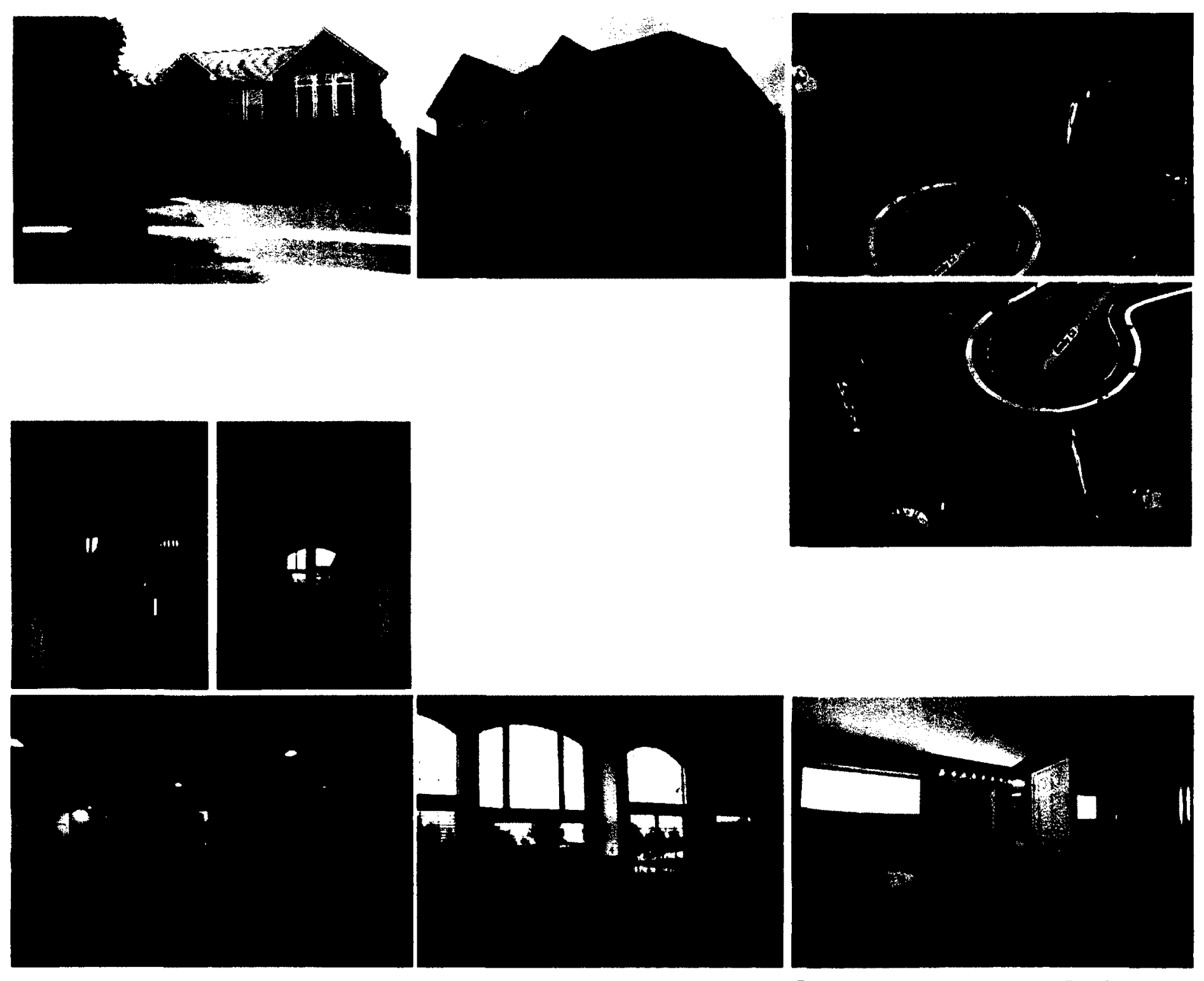

Fig. 37. Exterior and interior views of 1,2. and 3 Emily $\mathrm{Cl}$ Top Left + Middle : Typical style of houses built by Kimball Hill

Homes in Foxridge Farms subdivision. Centre Left : Photos of entry foyer. Bortom Left - Basement Bottom Center : Living Room. Bottom Right: M.Master Bathroom 
The action of repurposing foreclosed McMansions may become a mechanism to enhance the suburban quality of life, and foster a greater sense of community. This requires a carefully considered set of programs. To determine the most appropriate programs, several factors were considered. Firstly and perhaps most importantly; what would benefit the community? What are the day-to-day items people drive to the nearest strip mall or cluster of big-box stores to acquire? What specific programs could act as a social catalyst, thus encouraging a sense of community cohesion? This project is of course driven by the negative effects of the foreclosure crisis, and many of the people who live in these suburban neighborhoods have lost their jobs due to the economic downturn. How do the unemployed spend their time, and how could these specific programs cater to their needs and lifestyle? All of these questions were considered while choosing the programs, which include as follows:

Greenhouse/Community Garden - Residents will have an opportunity to rent a small plot of land or planter and grow their own produce. The majority of the greenhouse will be used for the production of fresh fruits and vegetables to be sold in the market and used for food preparation in the Bistro.

Market/Grocery - Residents may purchase produce grown on site in the greenhouse as well as locally produced food items. This will create an enhanced understanding of where food comes from and how it's grown - which is often times a distant thought for shoppers. Also, in the 'basement' level of the grocery, $\mathrm{dry}$ and frozen foods will be available, so as to reduce the number of car trips to the nearest Super-Centre. 
Bistro - An informal restaurant where one may purchase a light meal prepared with the produce grown in the greenhouse. Located in the center house, the bistro spills out into the front of the greenhouse.

Library - The nearest library is a 14 minute drive away. The library is seen as a key element in the development a community, for children and adults alike. The children's section of the library is adjacent to the play-space and the adults section merges into the bistro area, so one may pick up a book and enjoy a coffee. Visitors may sign out books on their own and donate their own material to the collection.

Children's Area / Play-space - This area is intended as a fun space for children to play while their parents tend to errands. It is open to above, so adults on the upper floor may keep a watchful eye. Large sliding doors allow the space to extend outside in the warmer months.

Presentation / Screening Room - Located on the ground and basement levels of the north side of the building, this space will be open to the general public and may be used for lectures, presentations, meetings, performances, information sessions, or screenings of special features. When not reserved, it may be used for an informal community movie night.

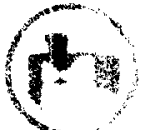

Workspace - Located on the 2 nd levels of the north and central portion of the building, the workspace is intended to be used by individuals as a home office away from home. Meant for entrepreneurs, or those conducting job searches, the workspace is a place for people to enhance their private businesses, or get back on their feet after an unfortunate job loss.

Open Program - Located on the top floor of the southwest portion of the building, this space does not have a defined program and may be used for community functions and events. 
Perhaps cooking classes can be held here to offer ideas and methods for how to use the locally grown produce.

Music/Sound Room - Located adjacent to the screening room, this is a space where music groups, musicians, or aspiring musicians can practice with privacy and enhanced soundproofing and acoustics.

Workshop / Assembly - This space provides the equipment necessary to build smaller-scale items, and hobbies, while meeting others that share a common interest. The wood-shop and assembly space are located in the basement of the centre of the building.

Nook - This is a multi- functional workspace with a higher degree of privacy. It is available for anyone who needs more space to think or concentrate, or it may be used for meetings.

As previously discussed, due to the 2007 sub-prime mortgage crisis and the financial crisis, many people lost their jobs and homes. For many of these people, these homes were their American Dream. By retooling these houses, the resulting building can become a space for those most affected by these crises to begin anew. Taken together, these programs offer a combination of social and cultural space currently lacking within suburban neighbourhoods. Primarily and most importantly, it will encourage new social relations between residents. Through the use of this new civic space, residents in the area can achieve a renewed sense of community, which is especially favorable in the wake of the subprime crisis.

In addition to new social interaction, this building aids the community by also catering to those who still find themselves unemployed or are restarting their careers. As mentioned earlier, 52 million people fall into the 'underemployment rate' while nearly 8 million people are out of work 
New York Times:

How the Unemployed Spend their Day

$\begin{array}{lll} & \text { \% } & \text { Hours } \\ \text { SLEEPING } & 21 & 5.04 \\ \text { LEISURE } & 15 & 3.6 \\ \text { HOUSEHOLD WORK } & 13 & 3.12 \\ \text { WATCHINGTV } & 12 & 2.9 \\ \text { SHOPPING } & 8 & 1.9 \\ \text { HOME REPAIR } & 7 & 1.68 \\ \text { CHILDCARE } & 6 & 1.44 \\ \text { EDUCATION } & 5 & 1.2 \\ \text { MEDICAL CARE } & 5 & 1.2 \\ \text { CARE OF OTHERS } & 4 & 0.96 \\ \text { SOCIALIZING } & 4 & 0.96 \\ \text { RELIGIOUSACTIVITIES } & 2 & 0.48 \\ \text { JOBSEARCH } & 1 & 24 \mathrm{~min} . \\ \text { OTHER } & 1 & 24 \mathrm{~min} .\end{array}$

For the Unemployed the Day Stacks up Differently. New York Times Survey. July. 2009. Source: hittp:/ www. nytimes.com/interactive/2009/07/31/business/ 20080801-metrics-graphic hem completely.66 As such, the building offers tools and resources necessary for conducting a job search, for those who are interested in re-entering the job force. In addition, the social interactions facilitated by the building also allow for business networking, which increases the odds in finding work opportunities. Others who have found themselves out of work have become interested in the idea of entrepreneurship. As they may not have space or resources ${ }^{67}$ available in their own homes, this building facilitates the opportunity to embark on these potential business ventures. A study done by the New York Times Magazine claims that people who have lost their jobs in the recent economic downturn spend 1 percent of their day, or 24 minutes, looking for work. This number could be vastly increased if they had a place to go. a home office away from home.' For the residents of the area who potentially work from home, the building is as convenient as a home office, but offers a professional-level space for businesses to thrive. ${ }^{68}$

Through repurposing the McMansion, not only does the surrounding community benefit from the new civic space, but the overall value of the community will likely increase. By extension, this combats a major contributor to the current housing crisis: declining house values due to an excess of foreclosures.

The funding of the project would be in part from the government (federal or municipal) as it is partially a civic building, due to its merit of social implications, and sustainable entities. In addition it could also be funded in part by the community itself, through its Homeowners

66 7.9 Million Jobs Lost." CNNMoney. Cable News Network 02 Juhy 2010. Web. 22 Mar. 2012. http:// money.cnn.com/2010/07/02/news/economy/jobs_gone_forever/indexhtm ?

67 These resources would include high-speed commercial grade internet and scan and copy services for 'office' businesses, and a full woodworking shop, tools and assembly room, for woodworkers and other small construction.

68 "How Different Groups Spend Their Day." The New York Times. The New York Times, 31 July 2009. Web. 14 Jan. 2012. shttp://www.nytimes.com/interactive/2009/07/31/business/20080801-metrics-graphichtmls. 
Association. If fully funded between these two entities, the commercial space could be rented, the profit of which would be reinvested in the building. However, it could also be funded in part by individuals who would own the commercial space outright, instead of simply renting from a Homeowners Association. 

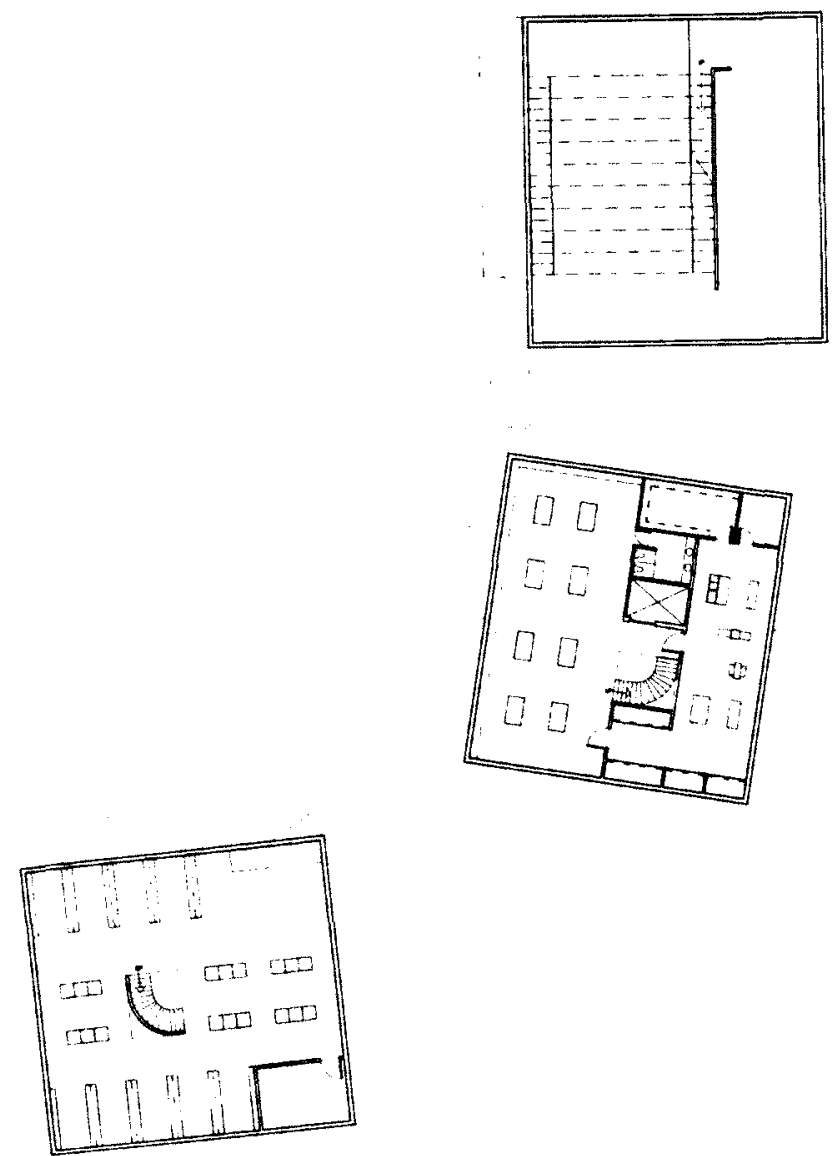

Presentation / Screening

Music Room

Assembly

Workshop

Market / Grocery 
Presentation / Screening

PlaySpace

Terrace

Children's Library

Adult's Library

Bistro

Greenhouse

Market / Grocery

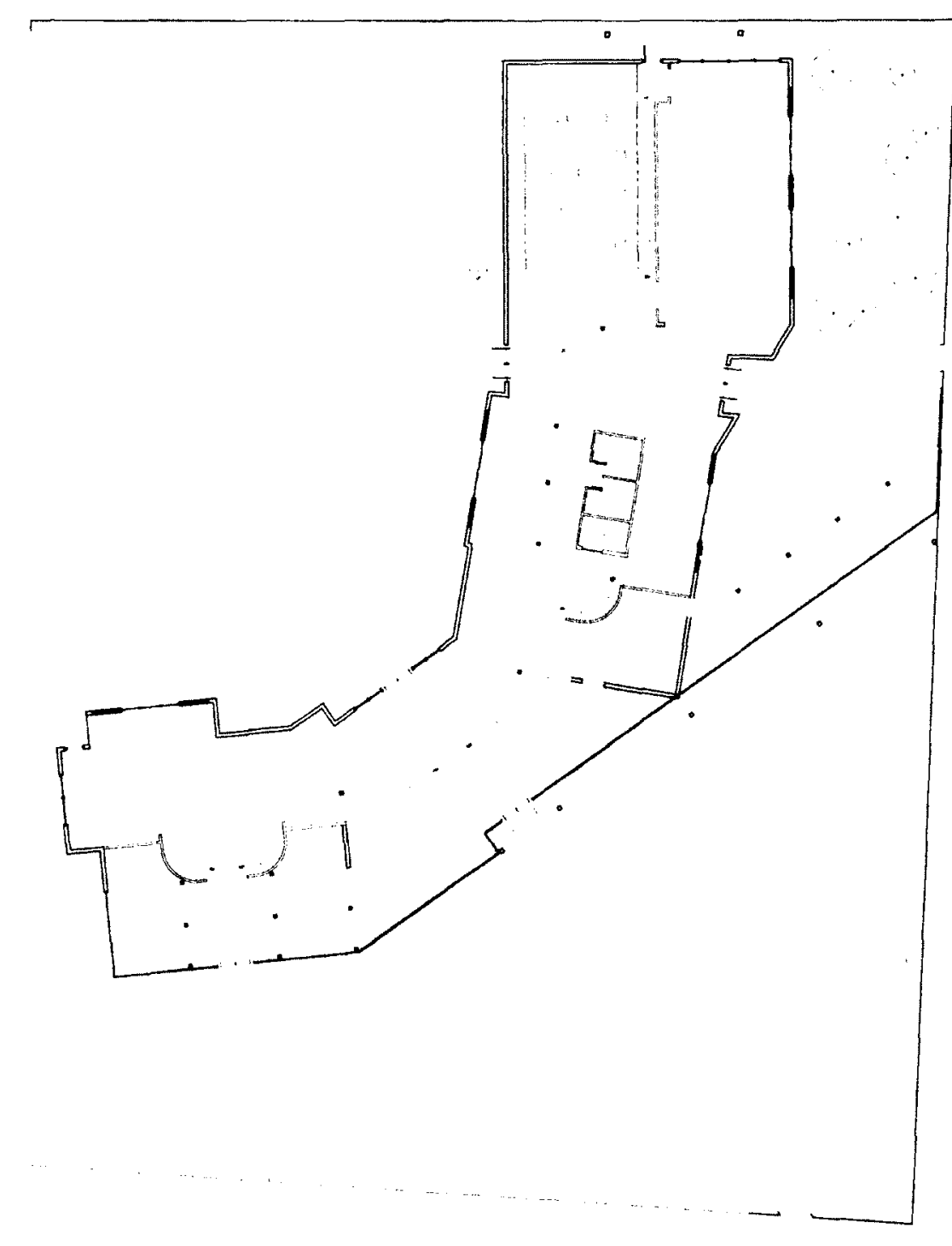

Public Garden 


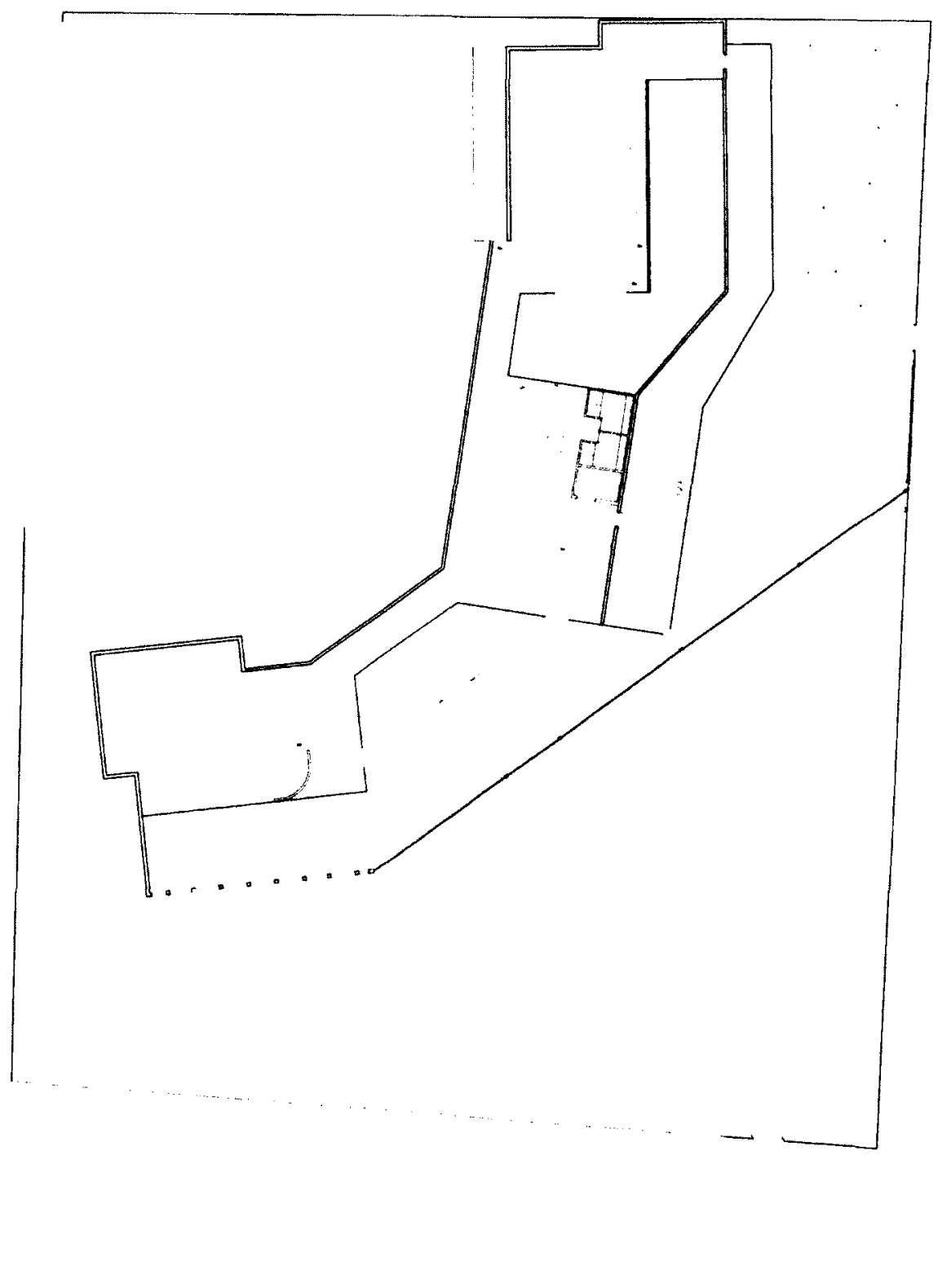

Fig. 40 Second Level Floor Plan. Approximate Scale 1500

SUBURBIA REDUX! Recycling the American I ream

Ai) 


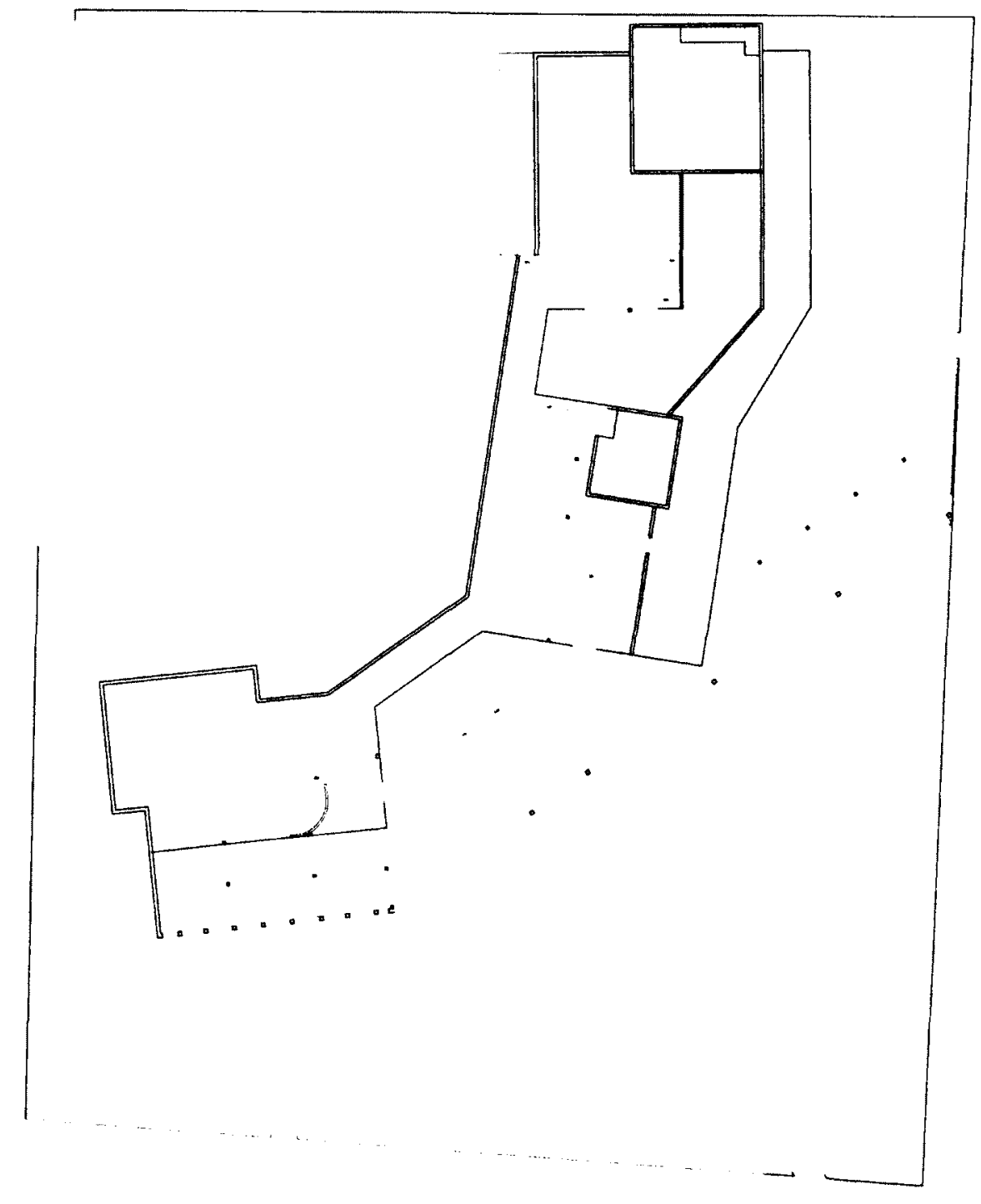




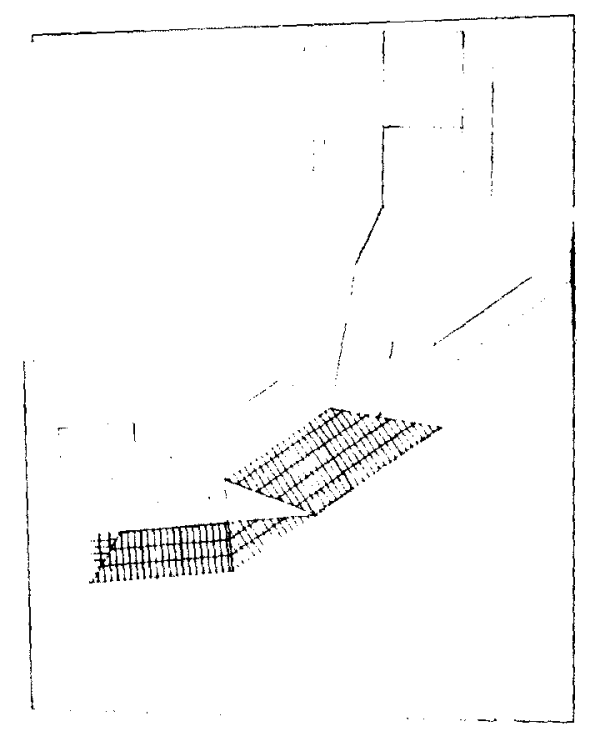

Fig. 42 Root i Site Plan 


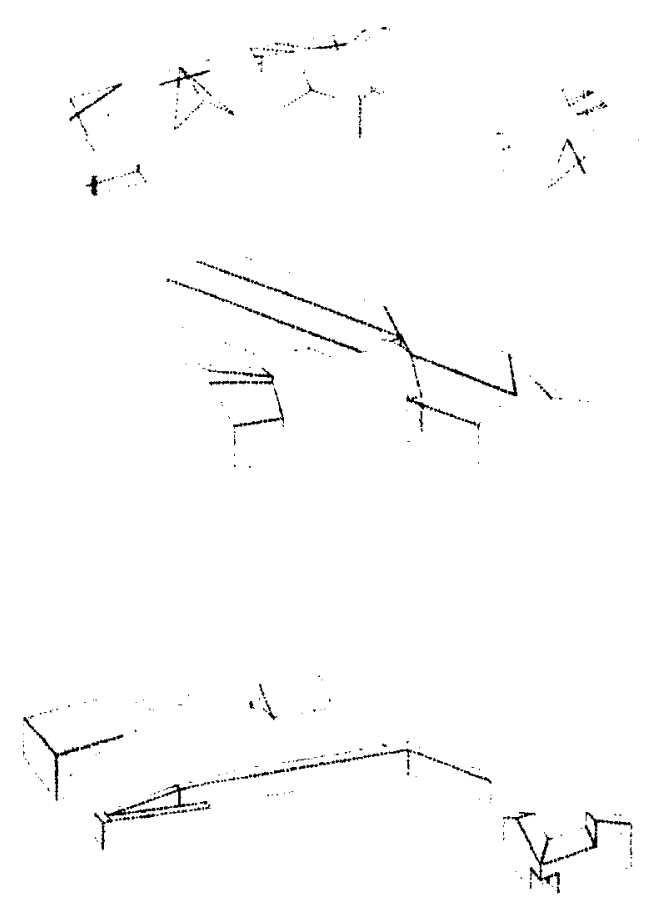

Fig. 43. Diagrammatic Representation of

House Manipulations.

- Original state of 1.2. and 3 Emily $C$

-3 Houses are bridged together.

Particular portions were cut and subtracted

- The Greenhouse portion was extended to

allow for more growing area.

- The front walkway and certain walls were

Final form of new building 

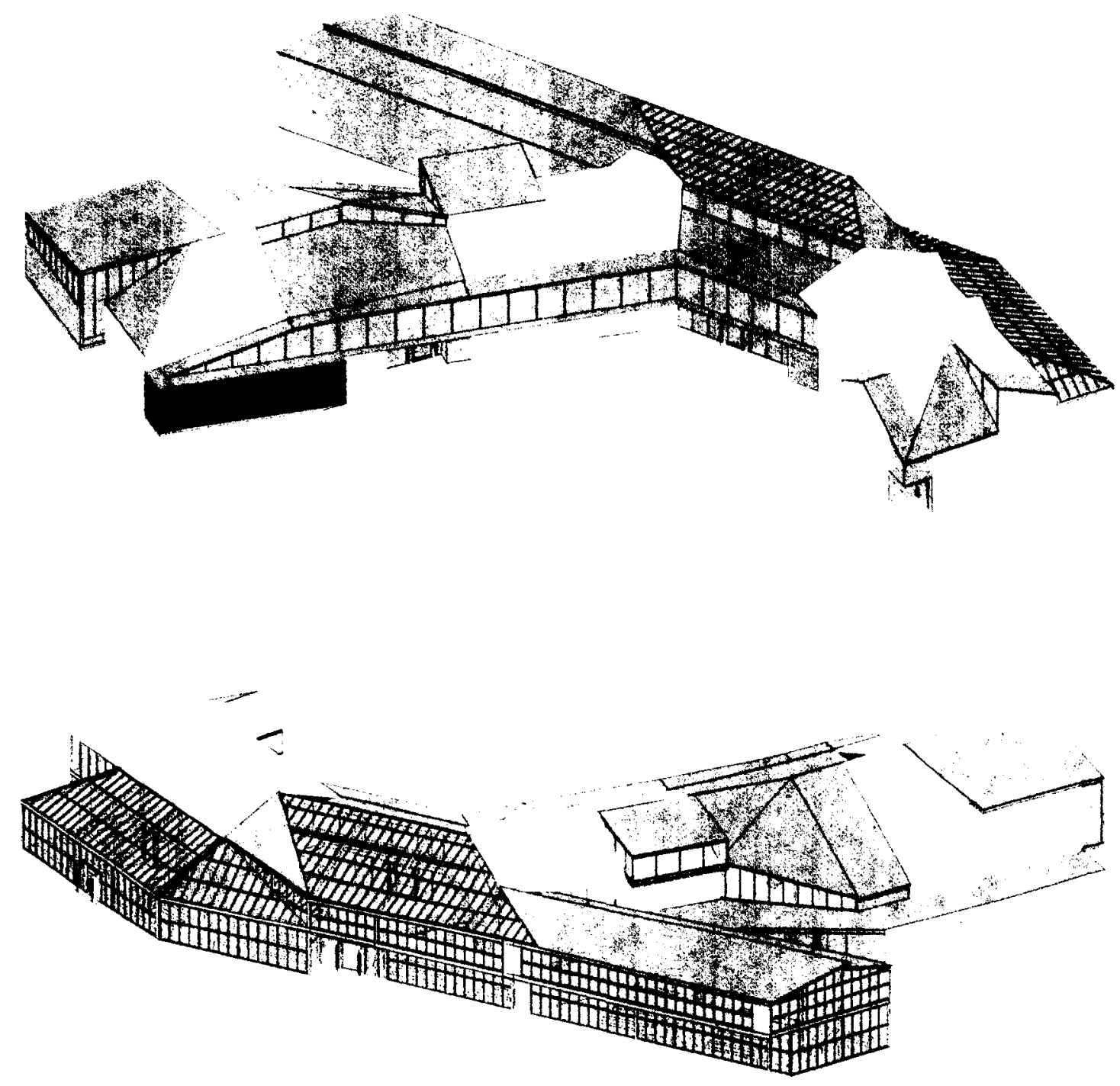

Fig. 44-45. Diagram of original and modified components Grey represents existing portions of orkginal houses. orange represents changes/alterations/ addions to produce final design 


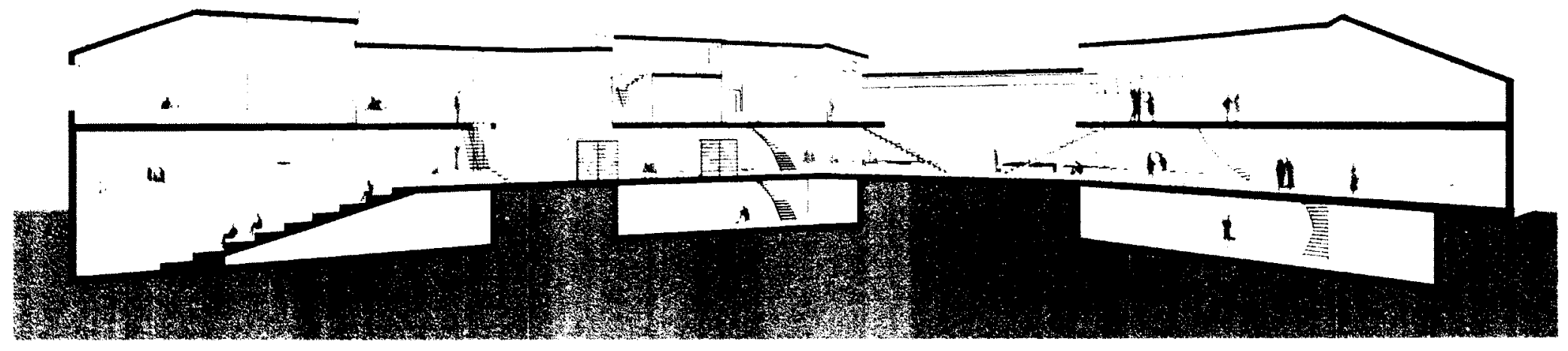

Fig. 46 Longrudinal Section 


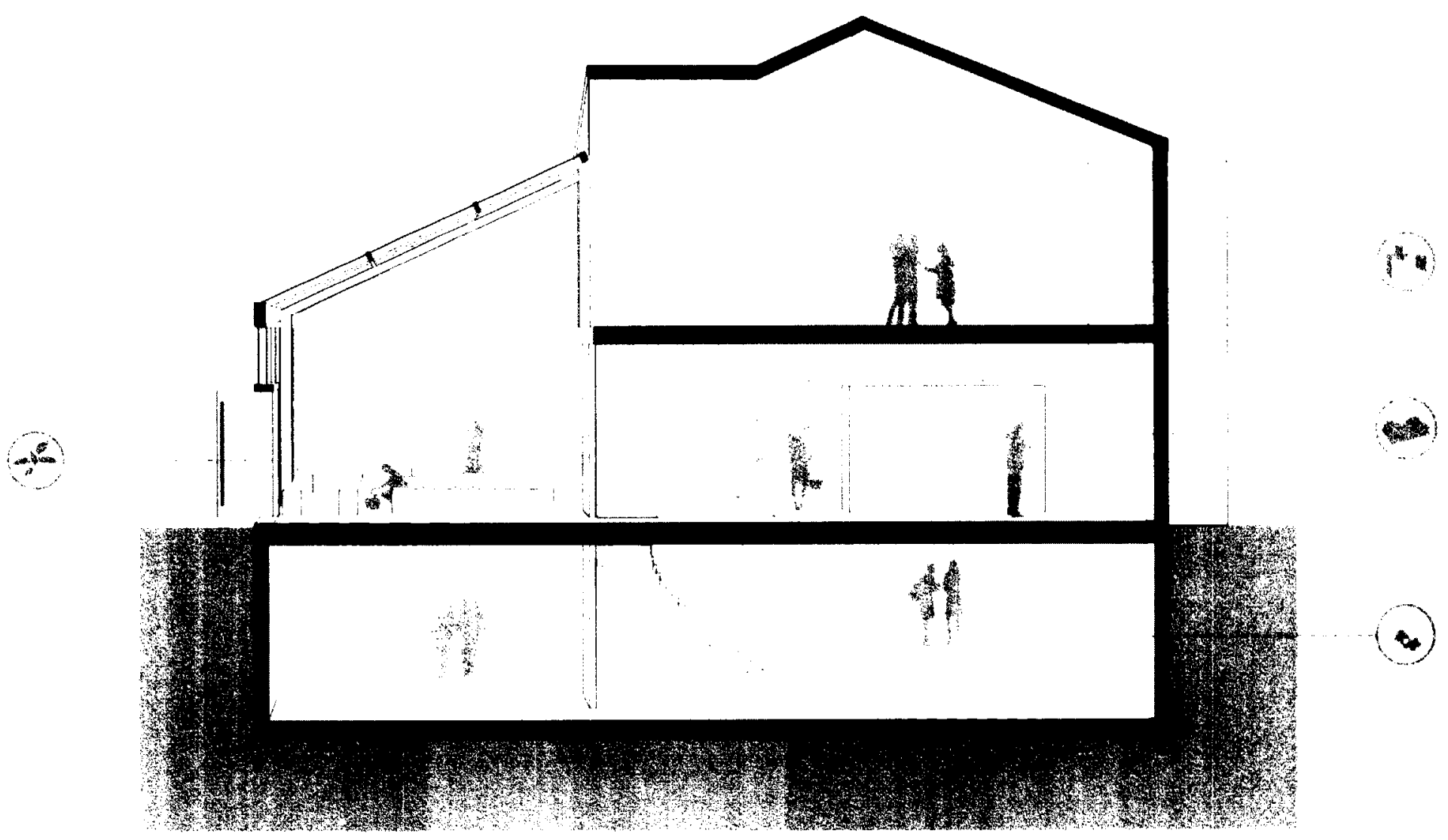

Fig. 47. Crosr Section

wa 


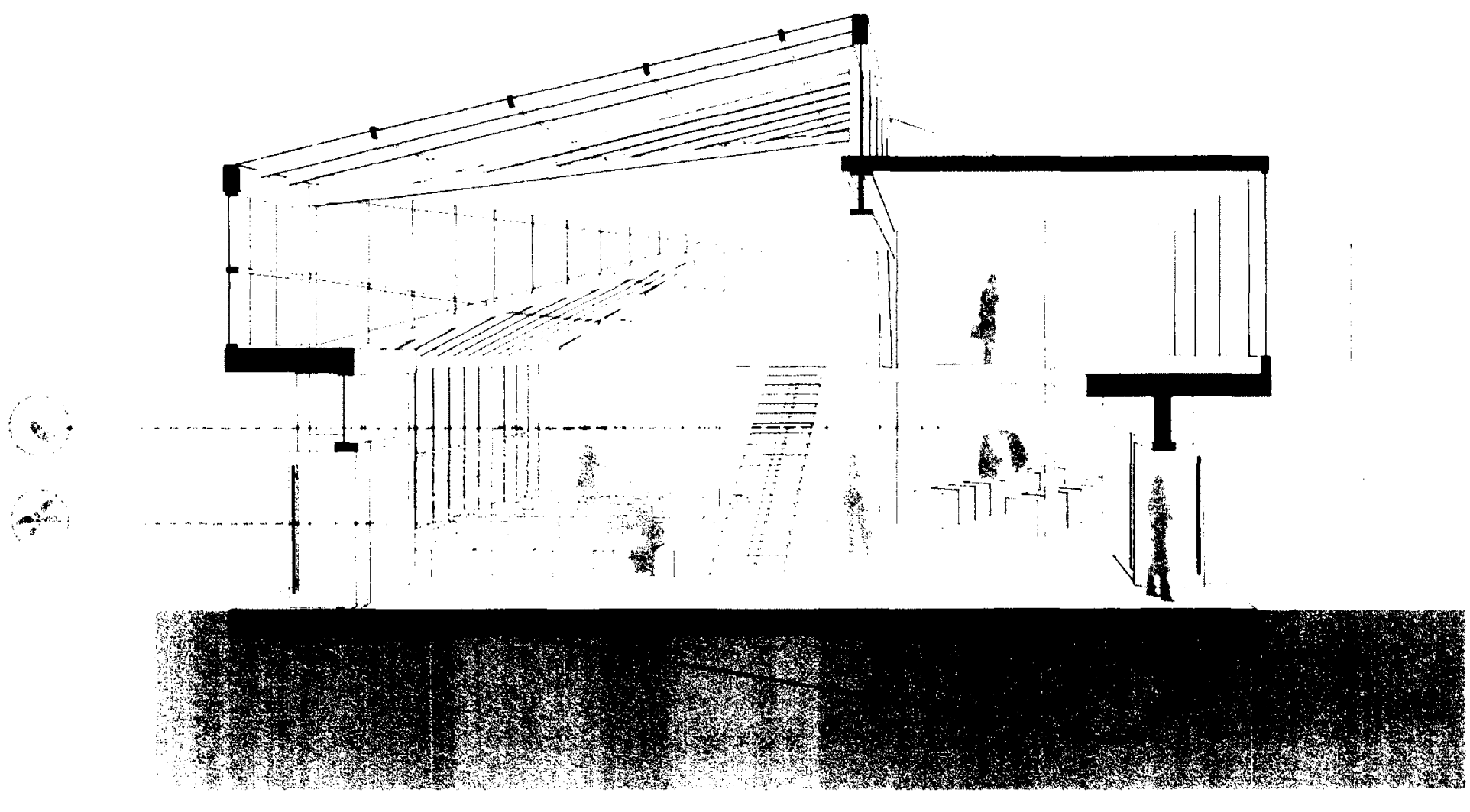

Fig. 48. Coss Section? 


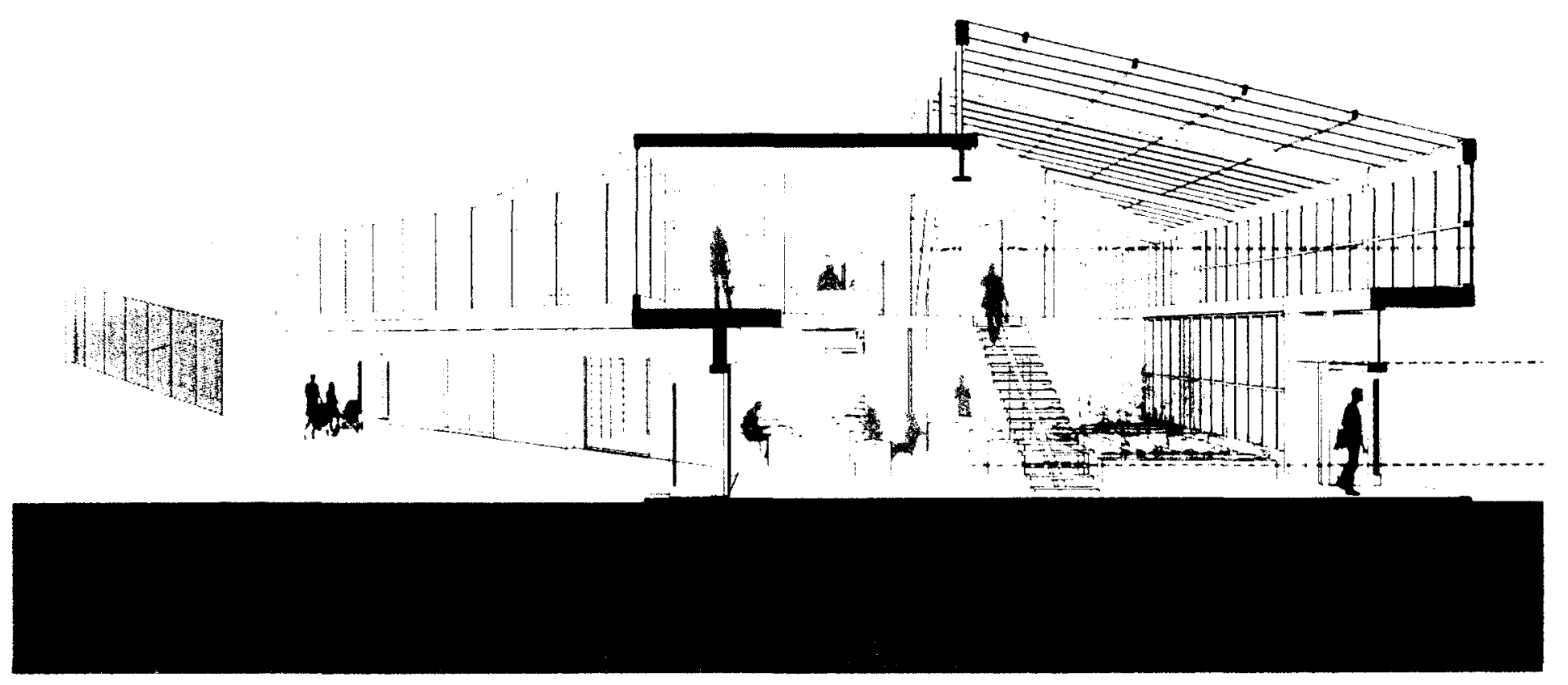

10 


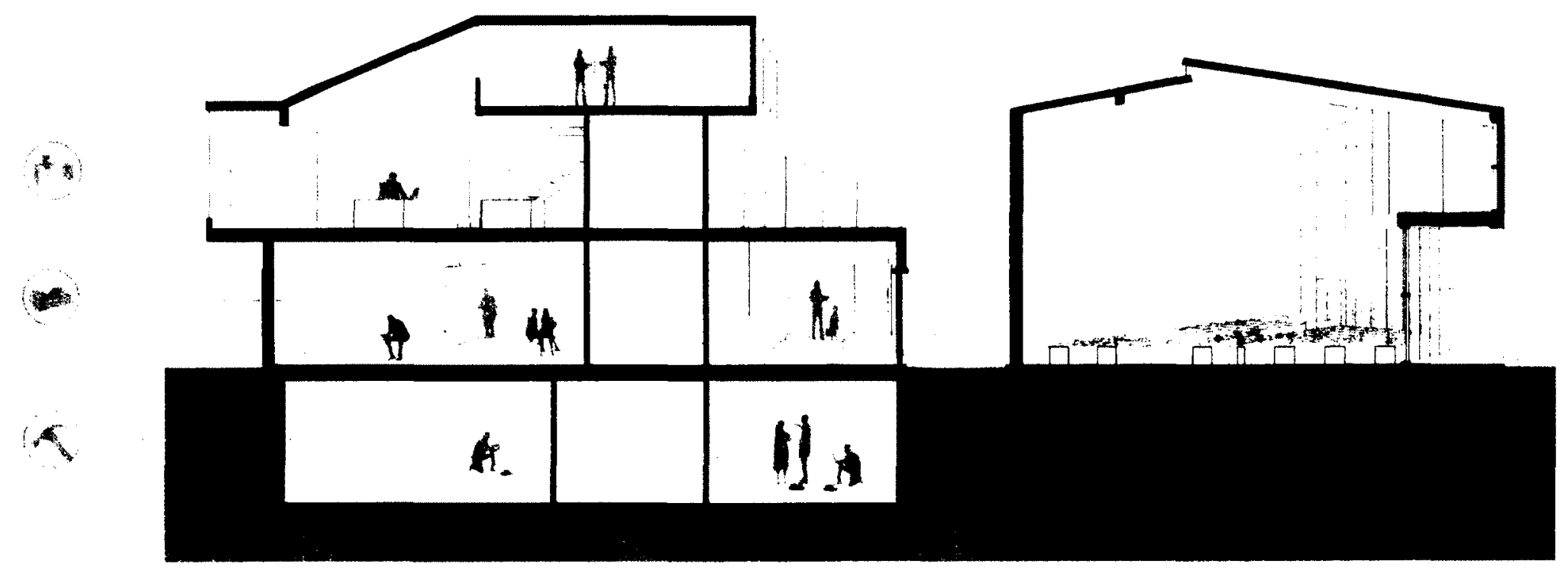

Fig. 50 Cross Section 4

tosent: 


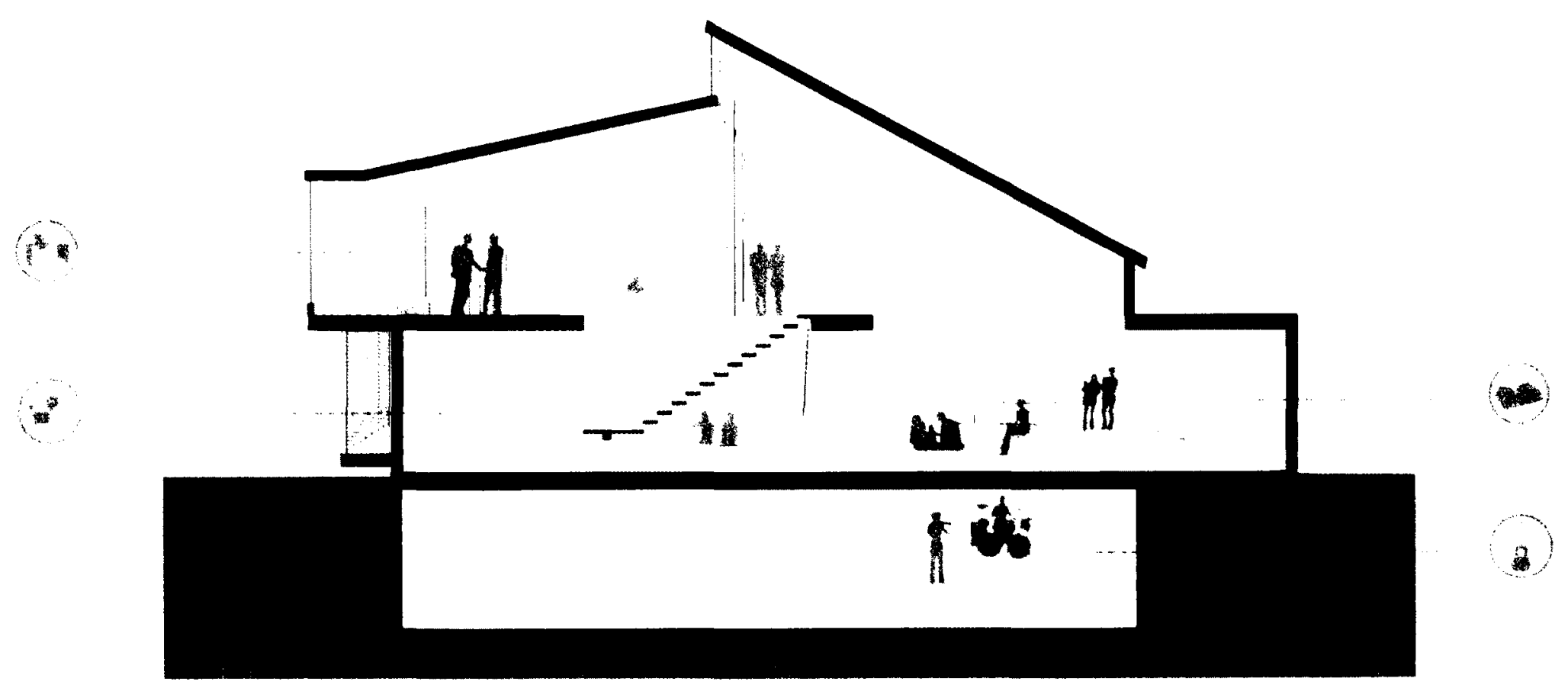

Fig. 51 Cioss Section: 


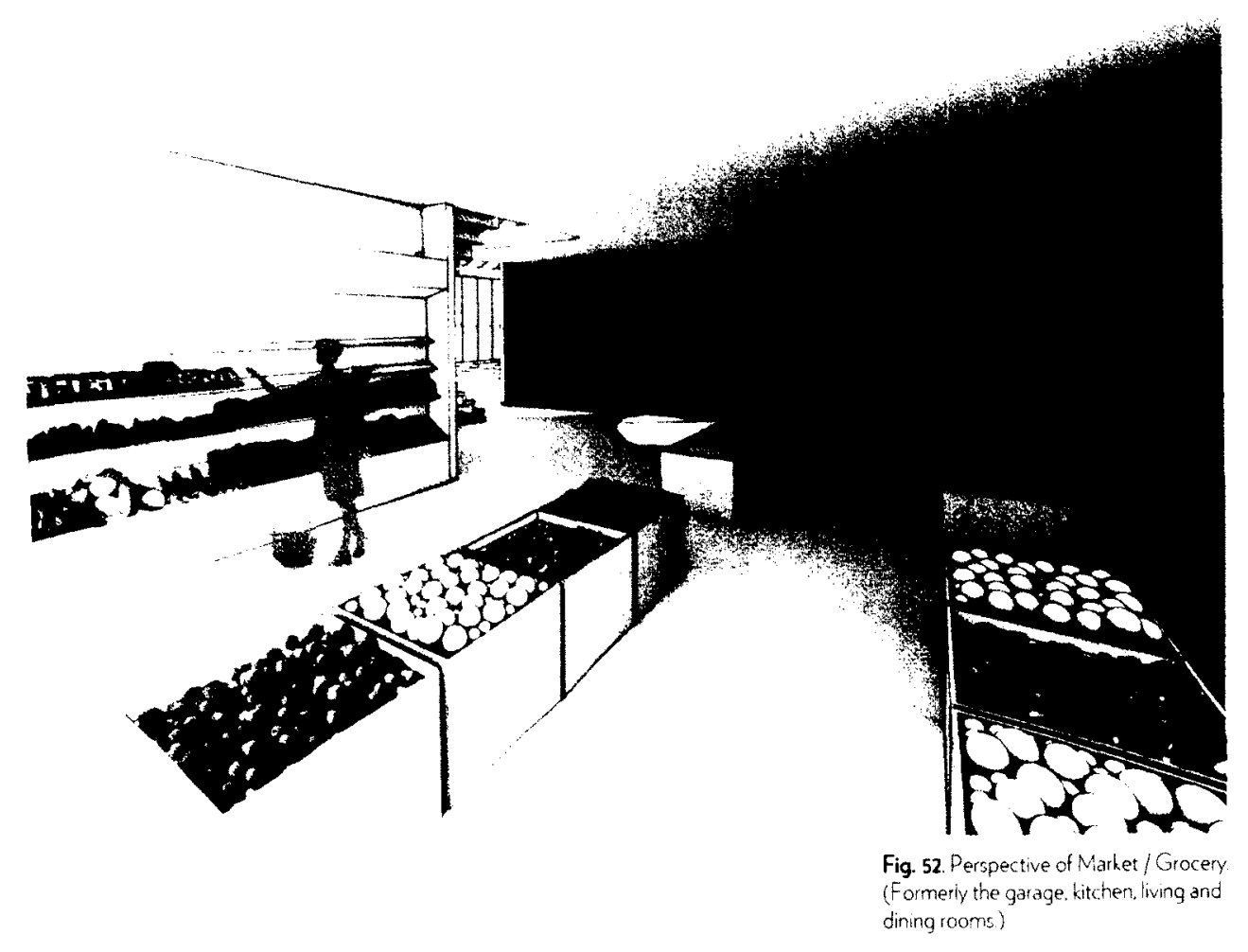



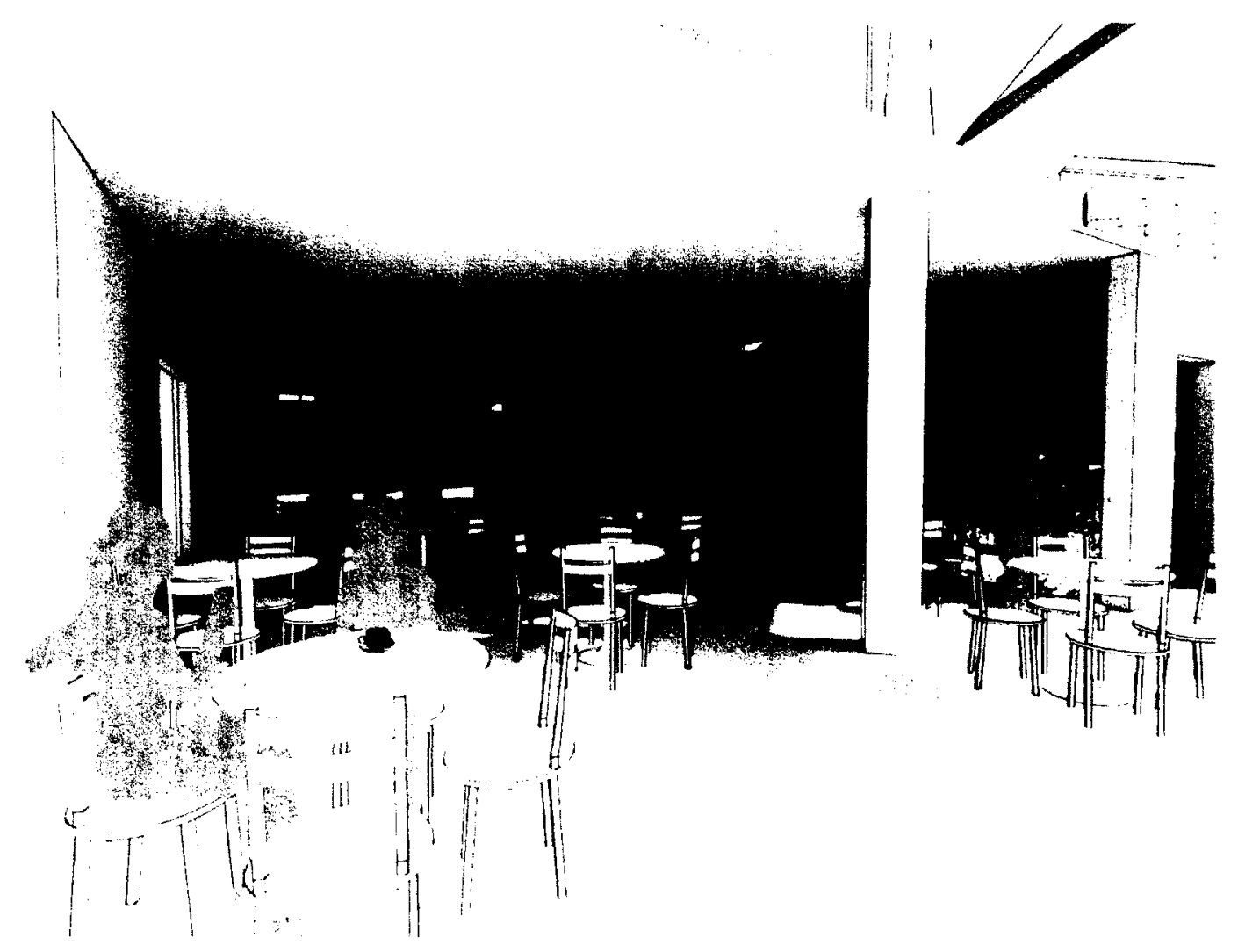

Fig. 53. Perspective of Bistro + Library (Fomerly the garage, living room and in-between space of 2 houses. 


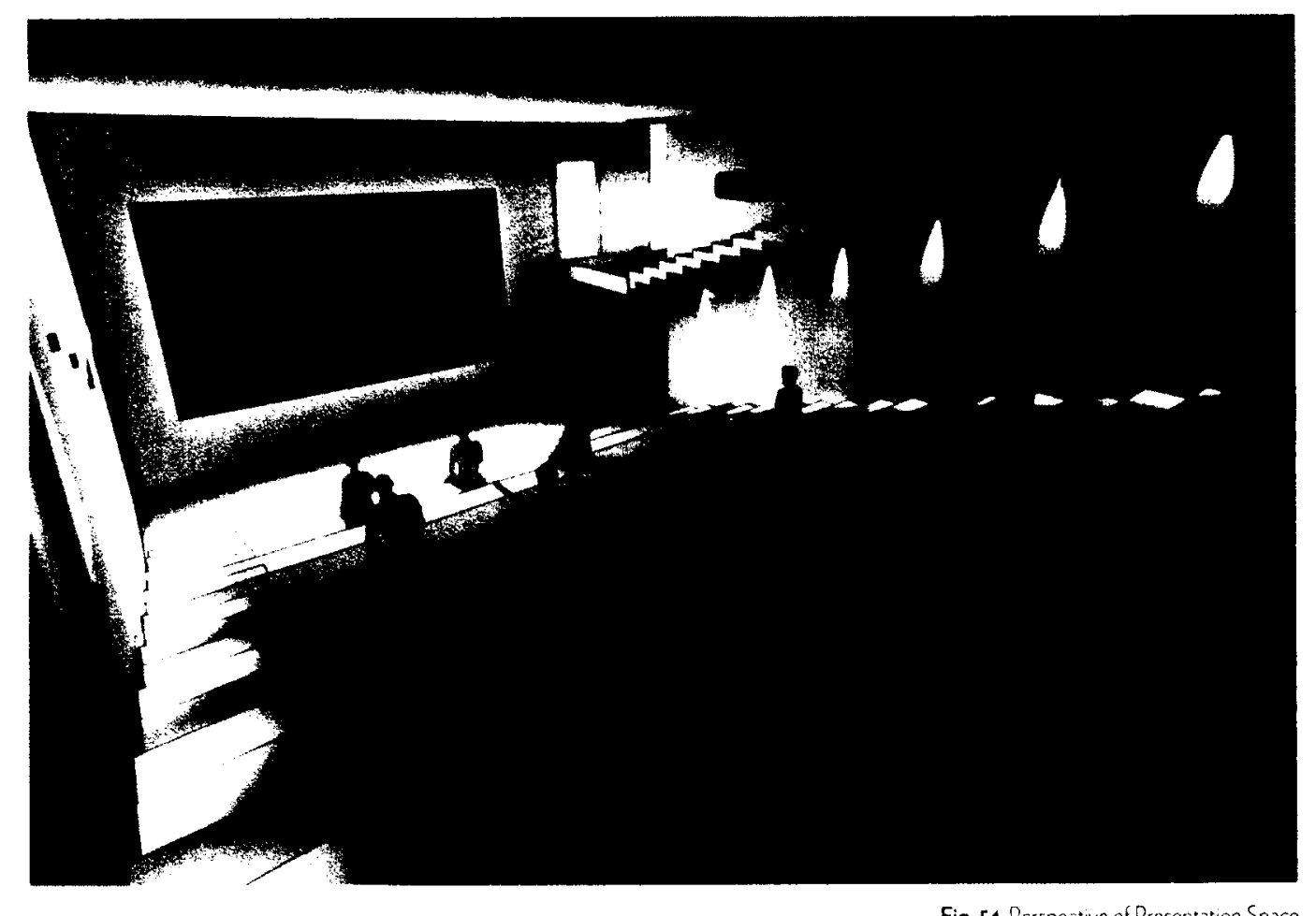

Fig. 54 Derspective of Presentation Space (Formerly the garage and basement) 

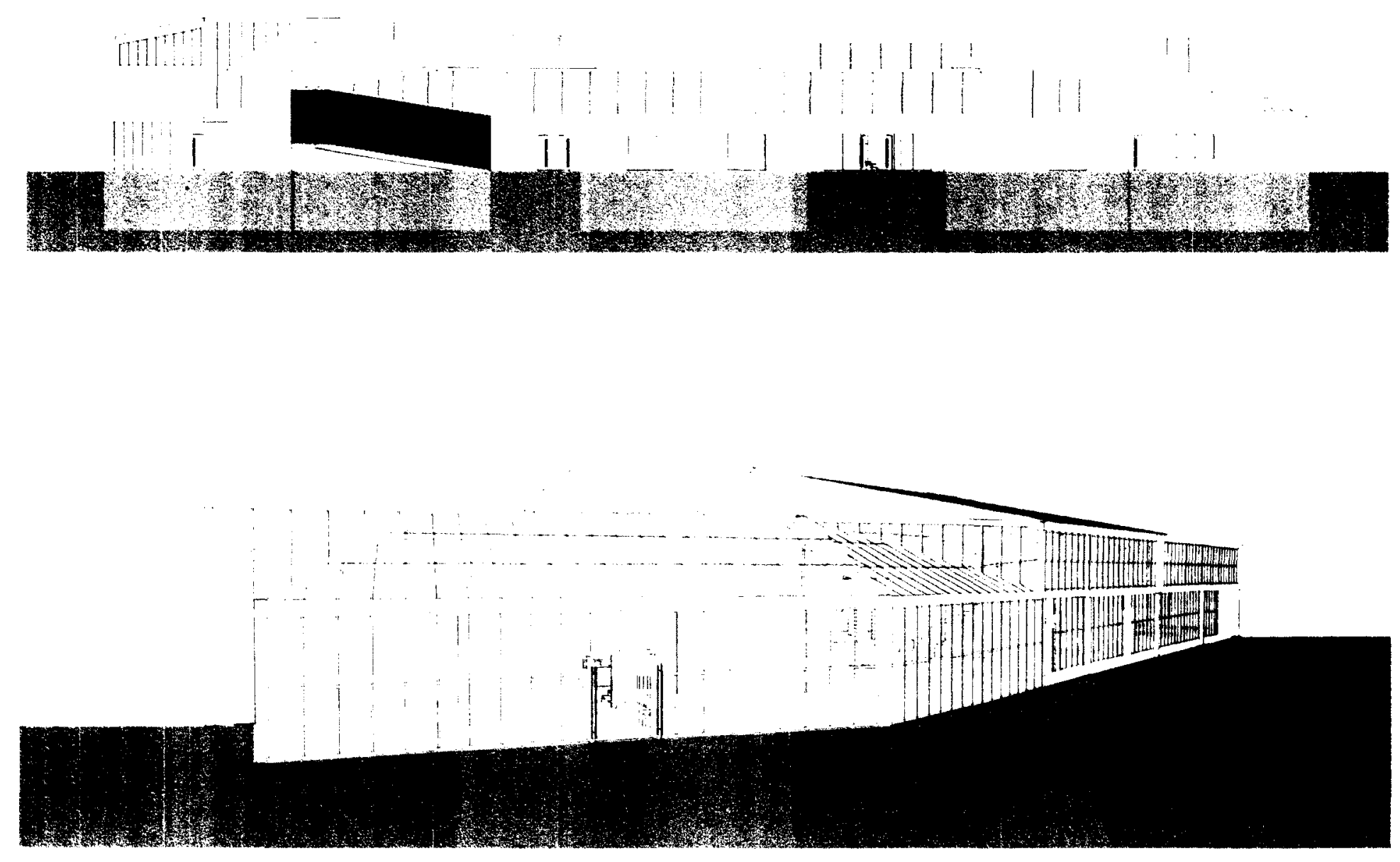

Fig. 55-56. Front Elevation. Rear Perspective Elevation 


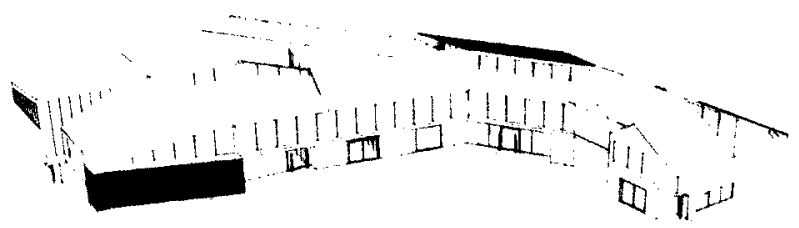

Fig. 57. Aerral View. Site Context.

SUBURBIA REDUX | Recyling the Amcrican Mrean

(9) 


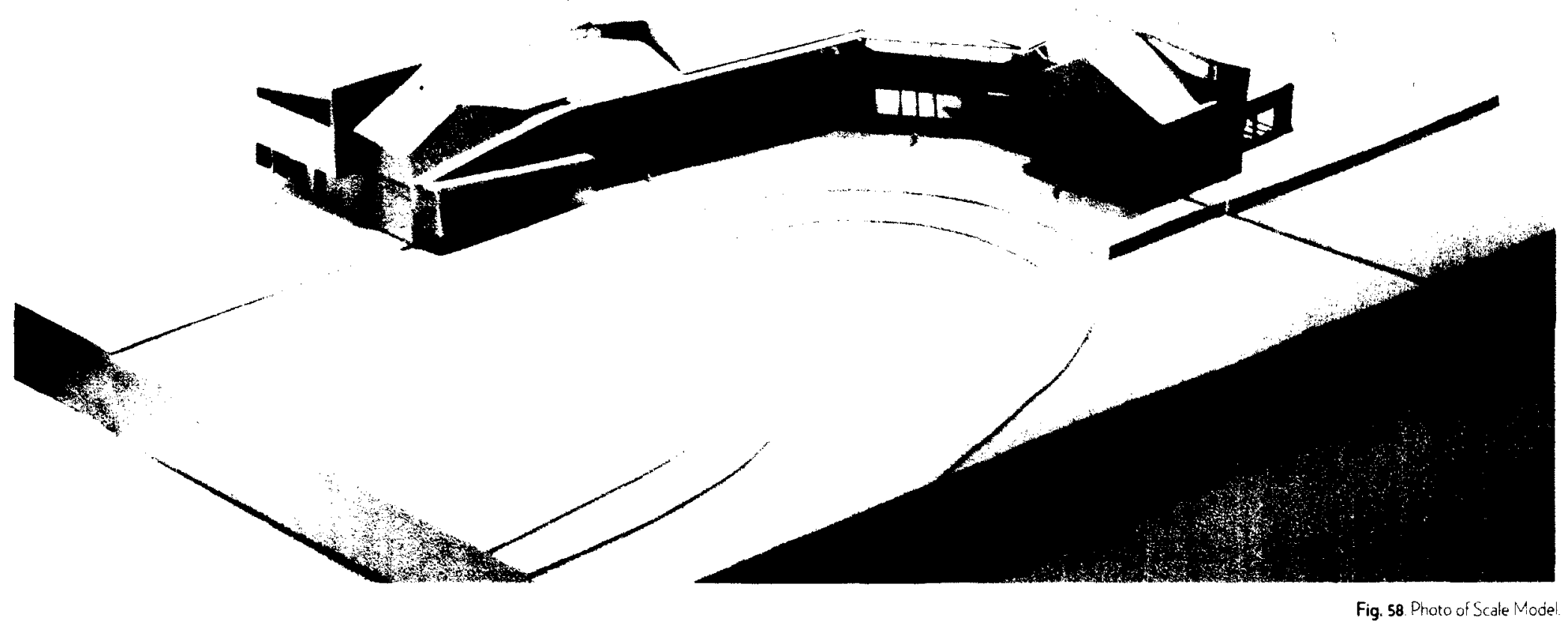




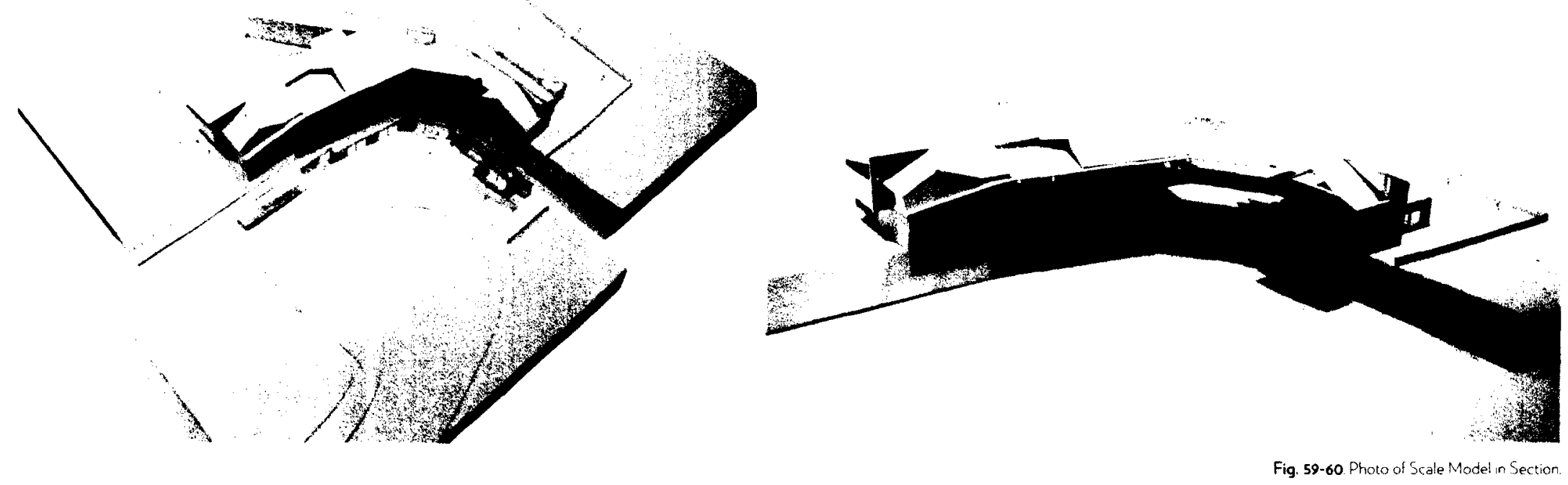



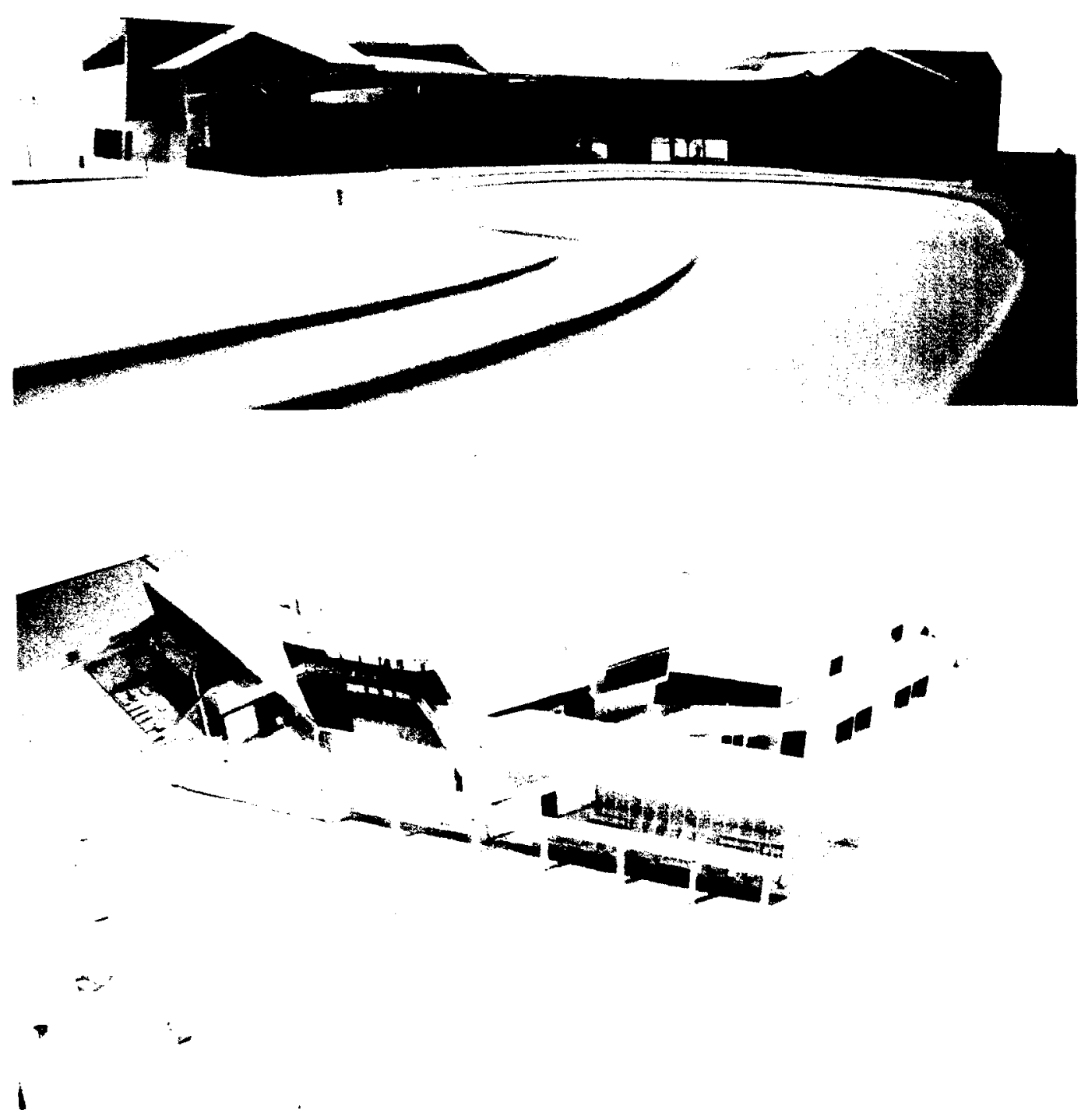

Fig. 61-62. Photo of Scale Model. Front and Rear 


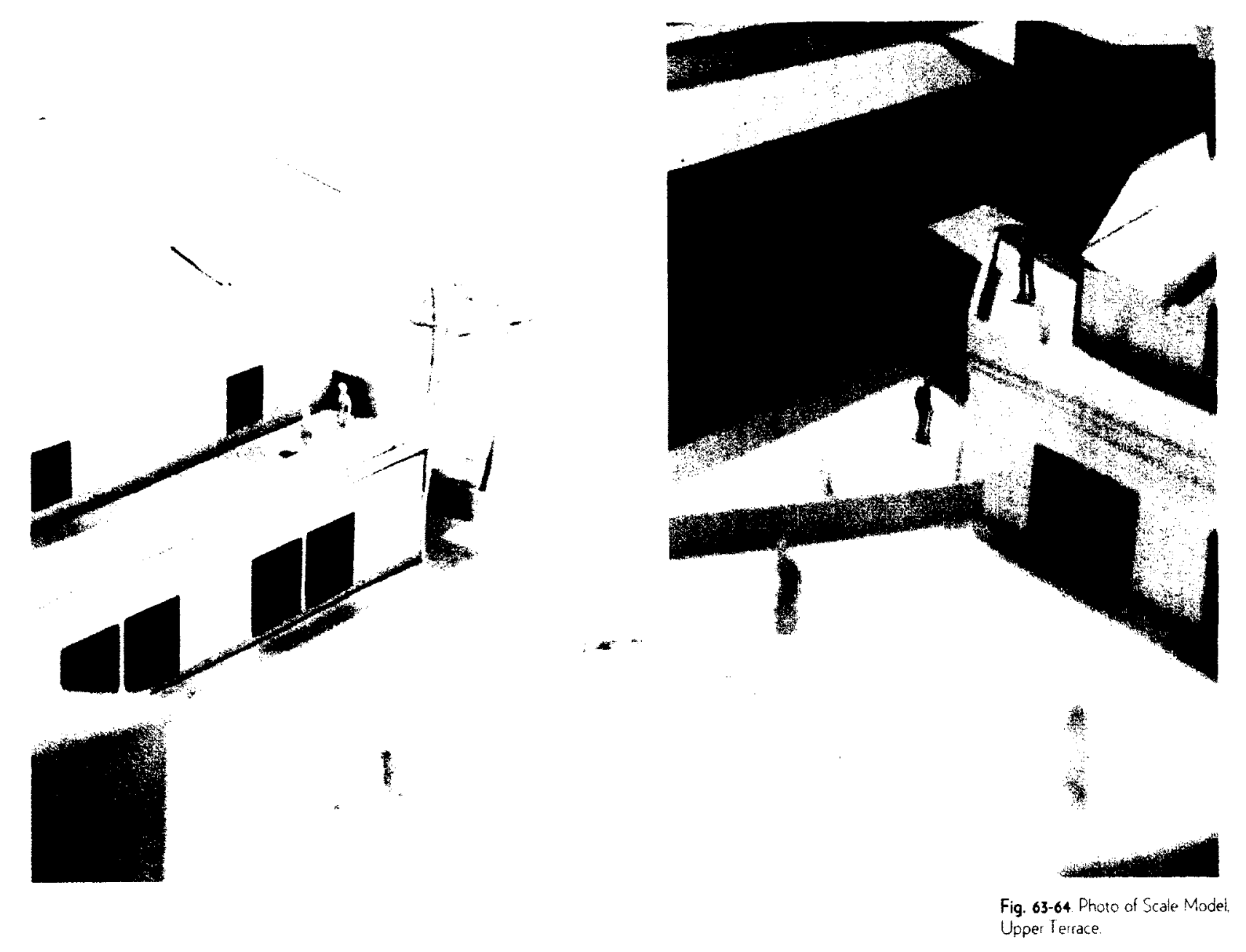




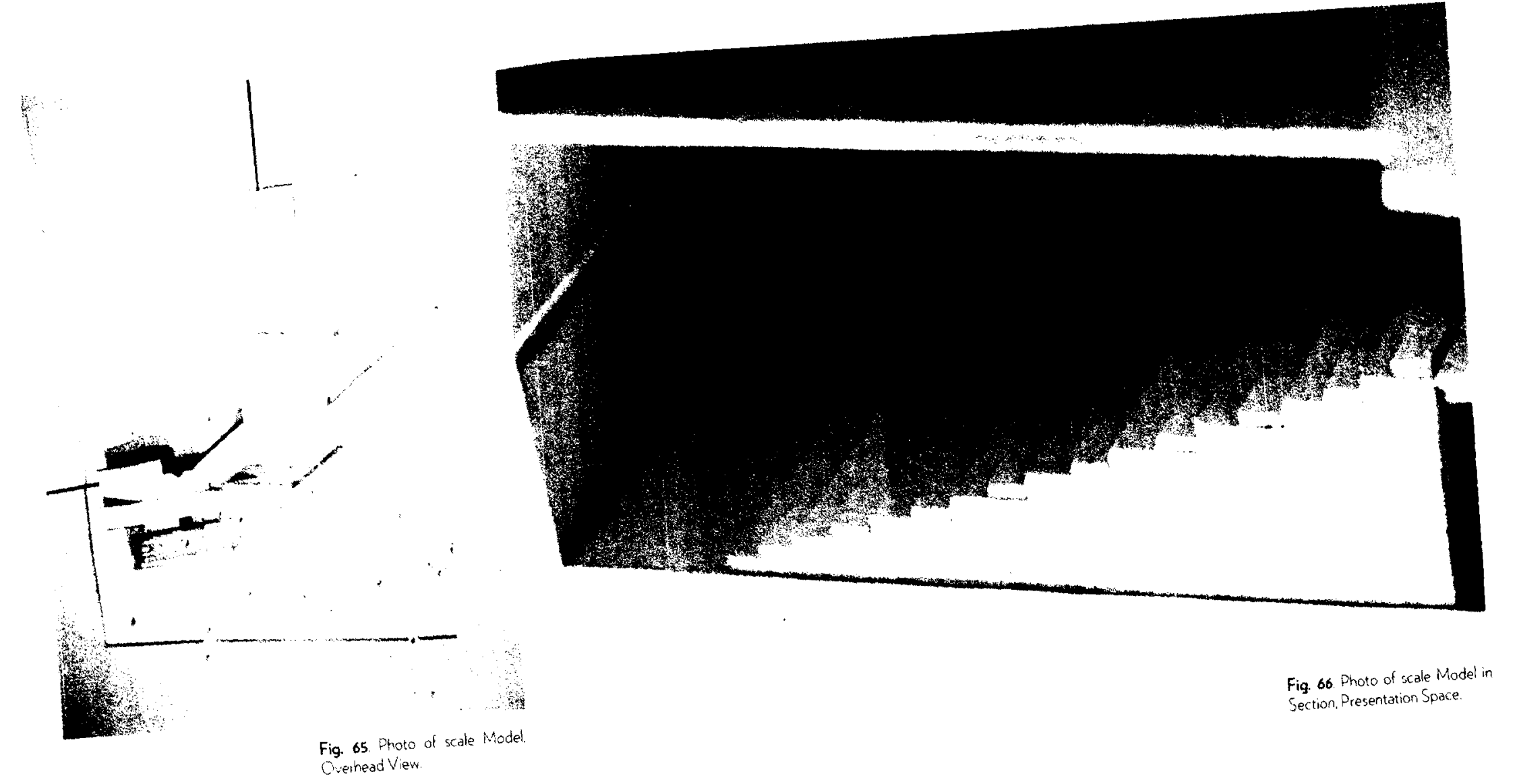




\section{CONCLUSION.}

Modern day suburbia is often thought in dismissive terms in architectural discourse. However, as this study shows, the desire for homeownership and "The American Dream" are so deeply ingrained in the American psyche that existing suburban typologies are not likely to disappear in the near future. If anything, the financial crisis has put suburbia back in the cultural consciousness. As the subprime crisis continues today, we must explore ways of enriching and re-imagining the suburban landscape.

When faced with the issue of abandoned buildings (such as old factories) in city cores, the architectural profession turned to adaptive reuse methods as a means to sustainably address this aging infrastructure. Many solutions for suburbia however, tend to revolve around the abandonment of existing typologies in exchange for entirely new, superiorly designed neighborhoods. This type of thinking is seen with the support of New Urbanist developments, where entirely new communities are built from scratch. It is also evidenced in the more avantgarde solutions proposed at the very recent MOMA exhibition, which seeks to respond to the subprime crisis through a variety of architectural proposals. 69

While these developments may be superior alternatives to existing types, this kind of thinking does not take into account the tens of millions of homes that have already been constructed and that may be lying vacant. By using adaptive reuse methods that have proven effective in urban centers, we can begin to address the many social and cultural shortcomings of suburbia. In effect, this project represents an evolution rather than a revolution. It looks to modify what already exists, allowing for a greater chance for its success and for its ideas to be explored in any neighbourhood throughout the country.

69 Four teams of architects across America are contributing to the exhibition entitled: Foreciosed: Rehousing the American Dream. http://www.moma.org/visit/calendar/exhibitions/1230 


\section{LIST OF ILLUSTRATIONS}

Figure 1. Aerial View of Levittown, NY. June, 1948 Source : Linck, Tony. Life Magazine (1948). Print.

Figure 2. Unknown Artist, 'Work, Buy, Consume, Die.' Stencil art, 2007 Source : http://workbuyconsumedie.com/

Figure 3. Graphic representation of the increase in house sizes from 1950 to 2004 Source : by Author

Figure 4. 'Your American Dream is Our Nightmare' Poster. Source : http://brunoibraheem.blogspot.ca/2011/11/your-american-dream-is-ournightmare.html

Figure 5. Protestors supporting the 'Occupy Wall Street' movement. Photo by: MarioTama Source : $h$ ttp://www.guardian.co.uk/commentisfree/cifamerica/2011/oct/17/occupy-wallstreet-goering

Figure 6. Advertisement addressing needs of Veterans returning from the War. Chicago Tribune, 1947

Source : http://www.statemuseumpa.org/levittown/one/b.html

Figure 7. Suburbia cartoon. Electrical Merchandising, July 1957. Source : http://www.statemuseumpa.org/levittown/one/b.html

Figure 8. '3 Magnet Diagram' created by Ebenezer Howard. 1902 Source : Howard, Ebenezer, and Frederic J. Osborn. Garden Cities of To-morrow. Cambridge, MA:M.IT. 1965. Print

Figure 9. Original Site Plan of Letchworth Garden City. By Howard, Parker and Unwin, 1903. Source : http://www.statemuseumpa.org/levittown/one/b.html

Figure 10. Welwyn Garden City. By Louis de Soissons, 1921 Source: $h$ ttp: //www.rickmansworthherts.freeserve.co.uk/howardi.htm\#snl

Figure 11. Chatham Village, Pittsburgh, PA. By Henry Stein and Clarence Wright, 1936 Source : http://www.franktoker.pitt.edu/1531/interwar.html

Figure 12. Aerial view of Celebration, FL Source : $h t t p: / / w w w . t i n o t o p i a . c o m / l o g / a r c h i v e / 2001 / 03 / 29 /$ markets_and_planning.htm 
Figure 13. View of Seaside, FL

Source: http://www.seasidefl.com/

Figure 14. Seaside Masterplan Source: http://www.seasidefl.com/

Figure 15. Advertisement for Levittown house styles c. 1947. Source : http://www.levittownbeyond.com

Figure 16. Aerial view of Levittown, NY.c. 1950

Source : http://www.modernhouse.com/allison/nytimes/blueprints-for-a-better-burb/

Figure 17. Construction materials gathered on site. June, 1948 Source: Linck, Tony. Life Magazine (1948). Print.

Figure 18. Newly constructed houses in Levittown, NY. 1948 Source : Linck, Tony. Life Magazine (1948). Print.

Figure 19. Floor plan for 1949 'Ranch House.' Source : Linck, Tony. Life Magazine (1948). Print.

Figure 20. 'Got a Big Life, Get a Big House' Billboard. Seattle, 2009

Source : http://seattlebubble.com/blog/2009/05/10/small-house-big-house/

Figure 21. 'McMansion' under construction.

Source : http://www.finehomebuilding.com/item/14933/can-mcmansions-help-solve-ourhousing-crisis

Figure 22. 'Crisis of Credit Visialized'.

Source: Jonathan Jarvis. www.crisisofcreditcom

Figure 23. "Watershed" by Mick Bouchet exhibited at the 2009 Venice Biennale. Source : http://bldgblog.blogspot.ca/2009/06/watershed-down.html

Figure 24. 'Foreclosures: Next Exit.' Figurative sign, unknown author. Source: http://www.commondreams.org/view/2011/05/01-0

Figure 25. Foreclosure signs on front properties Source : hittp://www.healthyrealestatenet/how-to-find-the-best-deals-in-foreclosure homes- for-sale/ 
Figure 26. Graph: US Properties with Foreclosure Activity. 2012

Source : National Real Estate Trends. U.S. Foreclosure Trends and Foreclosure Market Statistics. Web. 22 Mar. 2012. shttp://www.realtytrac.com/trendcenter/s.

Figure 27. America's Ideal Home Size. Trulia Interactive Survey, 2010 Source : http://info.trulia.com/indexphp?s=32055\&item=106117

Figure 28. Recession "Ghost Towns'.

Source : $h$ ttp://www.thefiscaltimes.com/Media/Slideshow/2011/08/03/9-Worst-Recession Ghost-Towns-in-America.aspx

Figure 29. Location of WIII and Kendall Counties. IL.

Source : http://www.smartdraw.com/examples/view/illinois+counties+map/

Figure 30. Aerial View of Foxridge Farms, IL. 1998-2008. Source: Google Earth

Figure 31. Site of Case Study, demonstrating severity of the foreclosure crisis in the selected area. Source : Information gathered from: http:/www.realtytrac.com/trendcenter/

Figure 32. Aerial View of Foxridge Farms, IL

Source : Google Earth

Figure 33. Homes currently in foreclosure in Foxridge Farms. Source : http//www.realtytrac.com/trendcenter/and and http://www.truliacom/for_sale/Bolingbrook,iL/foreclosure_lt/x_map

Figure 34. Amenities Map of area surrounding Foxridge Farms subdivision. Source : By Author

Figure 35. Aerial View of 1, 2, and 3 Emily Ct Bolingbrook, IL. Source: Google Earth / By Author

Figure 36. Program studies of existing floor plans of 1, 2, and 3 Emily $\mathrm{Ct}$. Source: Trulia Realtor/By Author

Figure 37. Interior and exterior views of 1,2, and 3 Emily $C t$ Source : http//www.realtytrac.com/trendcenter/and and http://www.truliacom/for_sale/Bolingbrook/L/foreclosure_t/x_map

Figure 38. Basement Floor Plan. Scale Approximately 1:500. Source : By Author 
Figure 39. Ground Floor Plan. Scale Approximately 1:500. Source: By Author

Figure 40. Second Floor Plan. Scale Approximately 1:500 Source: By Author

Figure 41. Third Floor Plan. Scale Approximately 1:500. Source: By Author

Figure 42. Roof / Site Plan. Source: By Author

Figure 43. Diagrammatic Representation of House Manipulations. Source: By Author.

Figure 44. Graphic Representing New and Existing Structure. Source: By Author

Figure 45. Graphic Representing New and Existing Structure. Source: By Author

Figure 46. Longitudinal Section Source: By Author

Figure 47. Cross Section 1 Source: By Author

Figure 48. Cross Section 2 Source: By Author

Figure 49. Cross Section 3 Source: By Author

Figure 50. Cross Section 4 Source : By Author

Figure 51. Cross Section 5 Source: By Author

Figure 52. Perspective of Market/Grocery. Source : By Author 
Figure 53. Perspective of Bistro/Library. Source : By Author

Figure 54. Perspective of Presentation Space. Source : By Author

Figure 55. Front Elevation Source: By Author

Figure 56. Rear Perspective Elevation Source : By Author

Figure 57. Aerial View, Site Context Source : By Author

Figure 58. Photo of Scale Model Source : By Author

Figure 59. Photo of Scale Model in Section Source : By Author

Figure 60. Photo of Scale Model in Section Source: By Author

Figure 61. Photo of Scale Model Front Source : By Author

Figure 62. Photo of Scale Model Rear Source : By Author

Figure 63. Photo of Scale Model Upper Terrace Source: By Author

Figure 64. Photo of Scale Model Upper Terrace Source : By Author

Figure 65. Photo of Scale Model Overhead View Source: By Author

Figure 66. Photo of Scale Model Presentation Space Source: By Author 


\section{BIBLIOGRAPHY.}

\section{-BOOKS-}

Adams, James Truslow. The Epic of America., Boston: Little, Brown, and, 1931. Print

Apgar. William C and Mark Duda, and Rochelle Nawrocki Gorey, The Municipal Cost of Foredosures: A Chicago Case Study. Print. February 27, 2005

Busch Akiko. Geography of Home: Writings on Where we Live. New York: Princeton Architectural Press, 1999. Print

Collins, George Roseborough, Christiane Crasemann. Collins, and Camillo Sitte. Camillo Sitte; the Birth of Modern City Planning. New York: Rizzoli, 1986. Print.

Cullen, Jim. The American Dream: A Short History of an Idea that Shaped a Nation. New York: Oxford University Press, 2003.

El-Khoury, Rodolphe and Edward Robbins. Shaping the City: Studies in History, Theory and Urban Design. New York. Routledge, 2004. Print

Engel, Kathleen C, and Patricia A. McCoy. The Subprime Virus: Reckless Credit, Regulatory Failure, and next Steps. Oxford: Oxford UP, 2011. Print.

Fishman, Robert. Urban Utopias in the Twentieth Century. Ebenezer Howard, Frank Lloyd Wright, and Le Corbusier. New York: Basic, 1977. Print.

Friedman, Avi, and David Krawitz. Peeking through the Keyhole: the Evolution of North American Homes. Montreal: McGill-Queen's UP. 2002. Print.

Hall, Peter Geoffrey. Cities of Tomorrow: an Intellectual History of Urban Planning and Design in the Twentieth Century. Oxford, UK: Blackwell, 2002. Print.

Hough. Michael. Out of Place: Restoring Identity to the Regional Landscape. New Haven: Yale UP. 1990. Print.

Howard, Ebenezer. To-morrow: A Peaceful Path to Real Reform. London: Routledge, 1998. Print. Jacobs, Jane. The Death and Life of Great American Cities. New York: Random House, 1961. Print 
Lowenstein, Roger. The End of Wall Street. New York: Penguin, 2010. Print.

Lowenstein, Roger. Origins of the Crash: The Great Bubble and Its Undoing. New York Penguin, 2004. Print.

Kelly, Barbara M. Expanding the American Dream: Building and Rebuilding Levittown. Albany: State University of New York, 1993. Print.

Jackson, Kenneth T. Crabgrass Frontier: the Suburbanization of the United States. New York, NY: Oxford UP, 1987. Print. p. 219-245

Morgenson, Gretchen, and Joshua Rosner. Reckles\$ Endangerment: How Outsized Ambition, Greed, and Corruption Led to Economic Armageddon. New York: Times / Henry Holt and, 2011. Print.

Mumford, Lewis. The City in History: Its Origins, Its Transformations, and lts Prospects. New York: Harcourt, Brace \& World, 1961. Print.

Public Housing: A New Conversation. Temple Hoyne Buell Centre for the Study of American Architecture. Columbia University, New York. 2009

Schwartz, Herman M. Subprime Nation: American Power, Globa/ Capital, and the Housing Bubble. Ithaca: Cornell UP, 2009. Print.

Shiller, Robert J. The Subprime Solution: How Today's Global Financial Crisis Happened and What to Do about $l$. Princeton, NJ: Princeton UP. 2008. Print.

Teaford, Jon C. The American Suburb: The Basics. Michigan: Routeledge, 2006. Print.

Techi, Cecilia. Exposes and Excess: Muckraking in America, 1900-2000. University of Pennsylvania Press, 2004. Pages 33-34

Turner, Frederick Jackson. The Significance of the Frontier in American History. Ann Arbor: University Microfilms, 1966. Print.

Winn, Joni. Braces, Gym Suits, and Early Morning Seminary: A Youthquake Survival Manual. Salt Lake City: Covenant Communications, 1985. Print.

Wright, Gwendolyn. Building the Dream: a Social History of Housing in America. Cambridge, MA: MIT 1983. Print. 


\section{-ARTICLES-}

7.9 Million Jobs Lost." CNNMoney. Cable News Network, 02 July 2010. Web. shttp://money.cnn.com/ 2010/07/02/news/economy/jobs_gone_forever/indexhtm).

Brennan, Morgan. "s The American Dream Of Home Ownership Dead? Not Really." Forbes Magazine, 11 Feb. 2011. Web. shttp://wwwforbes.com/sites/morganbrennan/2011/02/11/is-the-american-dream-ofhome-ownership-dead-not-really/s.

"Charter of the New Urbanism." Congress for the New Urbanism. Web. shttp://www.cnu.org/charters.

Fletcher, June. The McMansion Glut. The Wall street Journal. June 16, 2006. http://online.wsj.com/ article_email/SB115042445578782114-IMyQjAxMDE2NTEwNjQxMjYoWjhtml

"Facts on Foreclosure." Federal Deposit Insurance Corporation. Web. <www.fdic.gov/about/comein/ files/foreclosure_statistics.pdf?.

Great Places in America: Neighborhoods. American Planning Association. 2007. Web. shttp:// www.planning.org/greatplaces/neighborhoods/2007/chathamvillage.htm

Hamiton, Nolan. "The McMansion is Dead." Gawker. Web. 21 Nov. 2011. shttp://gawker.com/5855598/ the-momansion-is-deads.

"History of CMHC." Canada Mortgage and Housing. Web. <http://www.cmhe-schl.gc.ca/en/corp/ about/hi/indexcfm>.

Johnson, Dirk. "Briefly the New Frontier, Exurbs See a Bust After Boom." The New York Times. 20 Aug. 2011. Web. shttp://www.nytimes.com/2011/08/21/us/21encexurban.html?

pagewanted $=1 \&[r=2 \&$ sq $=$ m cmansion\&st $=c s e \& s c p=5$ >

Kamp. David "Rethinking the American Dream" Editorial Vanity Fair. Apr. 2009 shttp:// www.vanityfair.com/culture/features/2009/04/american-dream200904>

Knight, Meribah, and Bridget O'Shea. "Foreclosures Leave Pockets of Neglect and Decay." The New York Times. 27 Oct. 2011. Web. shttp://www.nytimes.com/2011/10/28/us/foreclosures-lead-to-crime-anddecay-in-abandoned-buildings.html?pagewanted=all>

Leinberger, Christopher B. "The Next Slum?" TheAtlantic. Mar. 2008. khttp://www.theatlantic.com/ magazine/archive/2008/03/the-next-slum/6653/2.

"National Archives: Our Documents." Servicemen's Readjustment Act (1944). Web. <http:// www.ourdocuments.gov/doc.php?doc=76?

National Real Estate Trends." U.S. Foreclosure Trends and Foreclosure Market Statistics. Web. 14 Oct. 
2011. 〈http://www.realtytrac.com/trendcenter/>.

Nocera, Joe. "Wake-Up Time for a Dream." New York Times, 11 June 2010. Web. shttp:// www.nytimes.com/2010/06/12/business/12nocera.htmls.

Perman, Cindy. Death of the McMansion: Era of Huge Homes is Over. Daily News. August 2010 shttp:// www.dailynews.co zw/indexphp/property/38-property/457-death-of-the-mcmansion-era-of-hugehomes-is-over.htmls.

Pommer, Richard. The Architecture of Urban Housing in the United States during the 1930s," Journal of the Society of Architectural Historians 37 (December 1978): 235-264.

Reynolds, Jakob. "Today's 'American Dream' Too Focused on Material Happiness." The Daily Toreador. Web. «http://www.dailytoreador.com/opinion/article_cl7fcb58-43b1-11e0-bd8a-0017a4a78c22.html)

Solomon, Christopher. "The Swelling McMansion Backlash." Web. 25 Aug. 2011. «http:// realestate.msn.com/article.aspx? cp-documentid=13107733).

"Unexpected Drop in Jobless Rate Fuels Optimism." msnbc.com. 04 Dec. 2009. Web. «http:// www.msnbc.msn.com/id/34272155/\#. T30c8Y73h3t).

"United States Department of Veterans Affairs." Gl Bill's History - Born of Controversy: The Gl Bill of Rights. Web. <http://www.gibill.va.gov/benefits/history_timeline/indexhtmb.

Wotapka, Dawn. "Builders' Dream Home: A McMansion-Sized Nightmare" The Wall Street Journal November, 2009. <http://blogs.wsj.com/developments/2009/11/20/builders-dream-home-a-mcmansionsized-nightmare/>.

Wallace, Edith B and Paula S Reed National Register of Historic Places Registration: Chatham Village. National Park Service. 2003. Web. <http://pdfhost.focus.nps.gov/docs/NHLS/Text/98001372.pdf>

Wilson, Alex and Jessica Boehland. Small is Beautiful: U.S. House Size, Resource Use, and the Environment Greenbiz.com, 2005, Web

\section{- VIDEO-}

The Crisis of Credit Visualized. By Jonathan Jarvis. Web. 22 Mar. 2012. shttp://crisisofcredit.com/s. Forbes.com Reuters Financial Blog, and NPR Planet Money have commended the simplicity and clarity of the video, as well as the attention to both macro and micro issues.

Manaugh, Geoff. "BLDGBLOG: Watershed Down." BLDGBLOG. 9 June 2009. Web. shttp:// bidablog.blogspot.ca/2009/06/watershed-down,htmls. 